\title{
Fischer-Tropsch Synthesis over Early Transition Metal Carbides and Nitrides: CO Activation and Chain Growth
}

Joshua A. Schaidle and Levi T. Thompson ${ }^{1}$

Hydrogen Energy Technology Laboratory and the Department of Chemical Engineering, University of Michigan, Ann Arbor, MI 48109, USA

\begin{abstract}
A series of transition metal carbide and nitride catalysts $\left(\mathrm{Mo}_{2} \mathrm{C}, \mathrm{Mo}_{2} \mathrm{~N}, \mathrm{~W}_{2} \mathrm{C}, \mathrm{W}_{2} \mathrm{~N}, \mathrm{VC}, \mathrm{VN}\right.$, $\mathrm{NbC}$, and $\mathrm{NbN}$ ) were prepared and evaluated for Fischer-Tropsch synthesis. The activity trend was $\mathrm{Mo}_{2} \mathrm{C} \sim \mathrm{W}_{2} \mathrm{C} \sim \mathrm{VN} \sim \mathrm{NbN}>\mathrm{Mo}_{2} \mathrm{~N} \sim \mathrm{W}_{2} \mathrm{~N}>\mathrm{VC} \sim \mathrm{NbC}$, with carbides and nitrides of the same parent metal exhibiting significantly different turnover frequencies (TOF). For example, the $\mathrm{Mo}_{2} \mathrm{C}$ catalyst exhibited a TOF of $0.36 \mathrm{~s}^{-1}$ at $300{ }^{\circ} \mathrm{C}$ whereas the TOF for the $\mathrm{Mo}_{2} \mathrm{~N}$ catalyst was $0.04 \mathrm{~s}^{-1}$. The carbides and nitrides favored light hydrocarbons $\left(\mathrm{C}_{1}-\mathrm{C}_{4}\right)$ exhibiting $\alpha$ values between $0.31-0.43$ at $290{ }^{\circ} \mathrm{C}$, and were active for the water-gas shift reaction. Results from temperature programmed desorption and reaction indicated that both the $\mathrm{Mo}_{2} \mathrm{~N}$ and $\mathrm{Mo}_{2} \mathrm{C}$ catalysts are capable of direct (without $\mathrm{H}_{2}$ assistance) $\mathrm{CO}$ dissociation; however, the activation barrier is much higher over $\mathrm{Mo}_{2} \mathrm{~N}$ than $\mathrm{Mo}_{2} \mathrm{C}$. The results also indicate that $\mathrm{C}-\mathrm{C}$ coupling over the $\mathrm{Mo}_{2} \mathrm{C}$ surface was facilitated by molecularly adsorbed $\mathrm{CO}$ (without $\mathrm{H}_{2}$ pre-adsorption), suggesting the primary pathway to $\mathrm{C}_{2+}$ hydrocarbons was through the oxygenate mechanism.
\end{abstract} Keywords: Fischer-Tropsch, carbide, nitride, CO dissociation, CO hydrogenation, CO insertion mechanism, oxygenate mechanism

1 Corresponding author.

E-mail address: $\underline{\text { tt @ umich.edu (Levi Thompson) }}$ 


\section{Introduction}

Carbon monoxide and hydrogen, simple building blocks available in syngas, can be combined to produce hydrocarbon and oxygenate-based fuels and chemicals via a number of different pathways including methanation, methanol synthesis, mixed alcohol synthesis, FischerTropsch synthesis (FTS), and Fischer-Tropsch-to-Olefins [1, 2]. All of these pathways require a catalyst that can perform some, if not all, of the following steps: (i) $\mathrm{H}_{2}$ activation, (ii) $\mathrm{CO}$ adsorption and activation, (iii) $\mathrm{C}-\mathrm{O}$ bond cleavage, (iv) $\mathrm{C}-\mathrm{C}$ bond formation, and (v) hydrogenation. Early transition metal carbides and nitrides have been demonstrated to be active for syngas conversion reactions, catalyzing the aforementioned reaction steps, albeit to varying degrees depending upon metal/non-metal atom type, reaction conditions, and presence of promoters [3-21]. Kojima et al. were among the first to investigate the $\mathrm{CO}$ hydrogenation activities of early transition metal carbides [3-5]. At atmospheric pressure, they found that carbides such as $\mathrm{TiC}, \mathrm{TaC}, \mathrm{Mo}_{2} \mathrm{C}, \mathrm{WC}$, and $\mathrm{W}_{2} \mathrm{C}$ produced primarily $\mathrm{CH}_{4}$, light hydrocarbons $\left(\mathrm{C}_{2}-\mathrm{C}_{4}\right), \mathrm{CO}_{2}$, and $\mathrm{H}_{2} \mathrm{O}$; however a small amount of higher hydrocarbons were also observed $\left(\mathrm{C}_{5+}\right)$. Ranhotra et al. compared the $\mathrm{CO}$ hydrogenation performance of $\mathrm{Mo}_{2} \mathrm{C}$ and $\mathrm{Mo}_{2} \mathrm{~N}_{\text {catalysts }}$ at atmospheric pressure and reported that the activity for the face centered cubic (fcc) phases were similar [6]. Kim et al. found that supported and unsupported $\mathrm{Mo}_{2} \mathrm{C}$ catalysts exhibited $\mathrm{CO}$ hydrogenation rates at atmospheric pressure similar to those for $\mathrm{Ru}$ [7], a metal that is known to be an effective $\mathrm{CO}$ hydrogenation catalyst. The effects of pressure [8] and promoters such as $\mathrm{K}$ $[12,17,19], \mathrm{Rb}[20]$ and $\mathrm{Ru} / \mathrm{Co}[9,10]$ have also been explored. While the utility of early transition metal carbides and nitrides for syngas conversion reactions has been demonstrated, very little is known about the reaction mechanisms over these materials. 
Recently, Medford et al. investigated the elementary steps of syngas reactions over $\mathrm{Mo}_{2} \mathrm{C}$ (001) using computational tools [22]. They reported that the Mo-terminated $\mathrm{Mo}_{2} \mathrm{C}(001)$ surface behaved similarly to $\mathrm{Ru} / \mathrm{Rh}$ with regards to carbon reactivity, but acts more like Mo/W with regards to oxygen reactivity. These results are consistent with recent work exploring the deoxygenation of biomass-derived intermediates over early transition metal carbides, which demonstrated that these materials favor C-O bond cleavage due to their strong affinity for oxygen [23-25]. Medford et al. also reported that the activation energy for CO dissociation over $\mathrm{Mo}_{2} \mathrm{C}$ was relatively low $(1.43 \mathrm{eV})$, and that the hydrogenation of $\mathrm{CO}$ led to significantly lower $\mathrm{CO}$ dissociation barriers [22]. Moreover, coupling of $\mathrm{HCO}$ species was observed to be more favorable than coupling of $\mathrm{CH}_{\mathrm{x}}$ species. These findings suggest that FTS over $\mathrm{Mo}_{2} \mathrm{C}$ catalysts may follow a mechanism involving oxygenate intermediates.

The key objectives of work described in this paper were to evaluate the FTS activities and selectivities of a series of early transition metal carbides and nitrides $\left(\mathrm{Mo}_{2} \mathrm{C}, \mathrm{Mo}_{2} \mathrm{~N}, \mathrm{~W}_{2} \mathrm{C}\right.$, $\mathrm{W}_{2} \mathrm{~N}, \mathrm{VC}, \mathrm{VN}, \mathrm{NbC}$, and $\mathrm{NbN}$ ) under industrially-relevant conditions and elucidate the mechanisms for production of key products over these materials. The materials were characterized by X-ray diffraction (XRD), nitrogen physisorption, and pulse chemisorption, and their catalytic properties were evaluated for FTS at 25 bar and $200-320^{\circ} \mathrm{C}$. The elementary reaction steps and the interactions of these materials with $\mathrm{H}_{2}$ and $\mathrm{CO}$ were probed using temperature programmed desorption (TPD) and temperature programmed reaction (TPRxn). The results provide insight into the preferred reaction pathway and the effect of the non-metal on reactivity, and can be used to guide further catalyst improvements.

\section{Experimental}

\subsection{Catalyst Preparation and Pretreatment}


High surface area carbide and nitride materials were synthesized using a temperature programmed reaction procedure [13,26-28]. The oxide precursors (particle size of $125-250 \mu \mathrm{m}$ ) were supported in a tubular quartz reactor and placed in a vertical furnace. The synthesis conditions for the Mo, $\mathrm{W}, \mathrm{V}$, and $\mathrm{Nb}$ carbides and nitrides are provided in Table S1. These parent metals were chosen because they form stable carbide and nitride structures, can be synthesized at temperatures below $1000{ }^{\circ} \mathrm{C}$, and can achieve moderate to high surface areas. The synthesis conditions were developed based on previous research in our group [13, 26-30] and other references [31]. Upon completion of the temperature program, the reactor was quenched to room temperature (RT), and the sample was then passivated with $1 \% \mathrm{O}_{2} / \mathrm{He}$ mixture flowing at $20 \mathrm{~mL} \mathrm{~min}^{-1}$ for $6 \mathrm{~h}$. This passivation step is required to prevent bulk oxidation of the catalyst upon exposure to air due to the pyrophoric nature of these materials.

The carbide and nitride catalysts were pretreated prior to FTS reaction rate measurements and chemisorption experiments. The catalysts were pretreated at atmospheric pressure in the gas used during synthesis flowing at $200 \mathrm{~mL} \mathrm{~min}^{-1}$ for $4 \mathrm{~h}$ at the maximum temperature used during synthesis (Table S1). For example, $\mathrm{Mo}_{2} \mathrm{C}$ was pretreated at $590{ }^{\circ} \mathrm{C}$ in $15 \% \mathrm{CH}_{4} / \mathrm{H}_{2}$. These conditions were chosen to remove the oxygen deposited during the passivation step and return the catalyst to its as-synthesized state.

\subsection{Materials Characterization}

The bulk crystal structures of the passivated carbide and nitride catalysts were characterized using XRD. The diffraction experiments were performed using a Rigaku miniflex $\mathrm{X}$-ray diffractometer with a $\mathrm{Cu}-\mathrm{K} \alpha(\lambda=1.54 \mathrm{~nm})$ radiation source and a $\mathrm{Ni}$ filter. A range of $20^{\circ}$ $<2 \theta<90^{\circ}$ was scanned at a rate of $5^{\circ} \min ^{-1}$ with a $0.02^{\circ}$ step size. 
Surface area and CO pulse chemisorption measurements were carried out using a Micromeritics 2910 AutoChem Chemisorption analyzer. Prior to these measurements, the catalysts were pretreated as described above, degassed in flowing He at a temperature $10{ }^{\circ} \mathrm{C}$ higher than the pretreatment temperature to remove any adsorbed $\mathrm{H}_{2}$, and then cooled to RT. The BET surface areas were measured using $\mathrm{N}_{2}$ physisorption at $77 \mathrm{~K}$. The $\mathrm{CO}$ pulse chemisorption experiments were performed at RT by repeatedly dosing the sample with pulses containing $5 \%$ $\mathrm{CO} / \mathrm{He}$ until complete saturation was achieved. The $\mathrm{CO}$ uptakes were determined from peak areas recorded using a thermal conductivity detector (TCD). Site densities were calculated assuming a stoichiometry of one $\mathrm{CO}$ molecule adsorbed per active site.

\subsection{Fischer-Tropsch Synthesis Experiments}

The FTS rate and selectivity measurements were carried out in a $4.6 \mathrm{~mm}$ I.D. stainless steel U-tube fixed bed reactor. Catalyst samples (40-200 mg) were supported on a quartz wool plug inside the reactor. The reactions conditions were 25 bar, $\mathrm{H}_{2} / \mathrm{CO}=2$, gas hourly space velocity (GHSV) of $9,600-42,000 \mathrm{~h}^{-1}$, and two temperature ranges: $200-250{ }^{\circ} \mathrm{C}$ and $270-320$ ${ }^{\circ} \mathrm{C}$. The GHSV was calculated by dividing the volumetric flow rate of the feed $\left(\mathrm{mL} \mathrm{h}^{-1}\right)$ by the volume of the catalyst bed $(\mathrm{mL})$. The two temperature ranges were selected to cover the typical temperatures used industrially for FTS, allow for adequate control of reaction temperature, and maintain differential reaction conditions. The amount of sample used was also adjusted to maintain CO conversions below 10\% (differential conditions). The samples were diluted with low surface area $\mathrm{SiO}_{2}\left(<1 \mathrm{~m}^{2} \mathrm{~g}^{-1}\right.$, particle size: $\left.125-250 \mu \mathrm{m}\right)$ to maintain a constant bed height and volume as well as to prevent channeling, avoid problems with axial dispersion, and minimize temperature gradients in the bed. In addition to the carbide and nitride materials, two commercial catalysts, $\mathrm{Fe} / \mathrm{SiO}_{2}$ and $\mathrm{Co} / \mathrm{Al}_{2} \mathrm{O}_{3}$, were obtained from Johnson-Matthey and used as bench-mark 
catalysts. The pretreatment conditions and reaction conditions for these materials were selected based on the supplier's recommendations.

$\mathrm{H}_{2}, \mathrm{CO}$, and $\mathrm{N}_{2}$ (internal standard) were introduced into the reactor using mass flow controllers and the feed lines to the reactor were heated to $150{ }^{\circ} \mathrm{C}$. The pressure of the system was set and maintained using a back pressure regulator located downstream of the reactor. All effluent lines were maintained at $200{ }^{\circ} \mathrm{C}$ to ensure that reaction products up to $\mathrm{C}_{10}$ remained in the vapor phase. Heavier products were condensed out in a trap; however, no liquids were observed after any of the $40 \mathrm{~h}$ time on stream (TOS) experiments. The concentrations of reactants and products in the effluent gas were analyzed using a Varian 3800 gas chromatograph equipped with two TCDs and a flame ionization detector. The GC responses for reactants and products were calibrated using gas standards (Scott Master Class) and gravimetrically-prepared liquid standards. The GC sampled the effluent gas every $45 \mathrm{~min}$.

The FTS performance of the carbide and nitride catalysts was evaluated using rate and selectivity measurements. The catalysts were allowed to stabilize for $8 \mathrm{~h}$ before steady-state rate measurements were recorded. Rates were recorded at each temperature for 4 h, allowing for 6 samples to be taken by the GC at each temperature. An example of the rate data as a function of TOS for the $\mathrm{Mo}_{2} \mathrm{C}$ catalyst over the temperature range of $200-250{ }^{\circ} \mathrm{C}$ is shown in Fig. S1. The product formation rate on a $\mathrm{C}_{1}$ basis was calculated according to Equation 1:

$$
r=\left(\frac{F_{\text {exit }}}{W_{\text {cat }}}\right) \sum_{i} C_{i} Z_{i} \quad \text { Eqn. } 1
$$

where $F_{\text {exit }}$ is the flow rate of the effluent gas from the reactor, $W_{\text {cat }}$ is the weight of catalyst in the reactor, $C_{i}$ is the molar concentration of component $i$ in the effluent stream determined from GC analysis, and $Z_{i}$ is the carbon number of component $i$. The components are the reaction products (i.e., hydrocarbons, alcohols and $\mathrm{CO}_{2}$ ). The product formation rate was calculated 
including and excluding the by-product $\mathrm{CO}_{2}$. For all experiments, the carbon balance closed to within $\pm 5 \%$.

The total selectivity (including $\mathrm{CO}_{2}$ ) on a $\mathrm{C}_{1}$ basis was determined using Equation 2:

$$
S_{j}=\frac{C_{j} Z_{j}}{\sum_{i} C_{i} Z_{i}}
$$

where $S_{j}$ is the total selectivity to component(s) $j$. Component(s) $j$ can be one compound (e.g., $\mathrm{CH}_{4}$ ) or a series of compounds such as $\mathrm{C}_{2}-\mathrm{C}_{4}$ hydrocarbons, $\mathrm{C}_{5+}$ hydrocarbons, or alcohols. The hydrocarbon only selectivity was calculated in a similar fashion except the concentrations of $\mathrm{CO}_{2}$ and alcohols were removed from the denominator. The olefin selectivity, $R_{n}$, was calculated as the molar ratio of olefins to paraffins for a given carbon number as shown in Equation 3:

$$
R_{n}=\frac{C_{o, n}}{C_{p, n}}
$$

where $n$ is the carbon number, $C_{o, n}$ is the molar concentration in the effluent stream of olefin with carbon number $n$, and $C_{p, n}$ is the molar concentration in the effluent stream of paraffin with carbon number $n$. Based on the Anderson-Schulz-Flory (ASF) model [32, 33], the chain growth probability factor, $\alpha$, was determined for each catalyst using the product distribution and Equation 4:

$$
m_{n}=(1-\alpha) \alpha^{n-1}
$$

where $m_{n}$ is the mole fraction of a hydrocarbon with chain length $n$.

\subsection{Temperature Programmed Desorption and Reaction Experiments}

The TPD and TPRxn experiments were carried out in a Micromeritics 2910 AutoChem Chemisorption analyzer. The analyzer was equipped with a TCD and a Balzers Instruments ThermoStar GS300 quadrupole mass spectrometer (MS) for online analysis of the effluent 
stream from the reactor. Approximately $100 \mathrm{mg}$ of catalyst sample was loaded into a $15 \mathrm{~mm}$ I.D. quartz U-tube reactor and supported on a quartz wool plug. The mass of catalyst loaded was varied to achieve the same total number of $\mathrm{CO}$ adsorption sites (based on the $\mathrm{CO}$ uptake of the materials determined using $\mathrm{CO}$ pulse chemisorption). Prior to analysis, the $\mathrm{Mo}_{2} \mathrm{C}$ and $\mathrm{Mo}_{2} \mathrm{~N}$ catalysts were pretreated as described earlier. After pretreatment, the temperature was increased by $10{ }^{\circ} \mathrm{C}$ and the catalyst sample was degassed in flowing He for $0.5 \mathrm{~h}$. The catalysts were then cooled in He and were ready for analysis. It should be noted that all experiments carried out in the chemisorption analyzer were performed at atmospheric pressure. The experimental details for the various TPD and TPRxn experiments are discussed below.

For the $\mathrm{H}_{2}-\mathrm{CO}$ TPRxn experiments, the catalyst sample was exposed to a flowing mixture of $\mathrm{H}_{2}$ and $\mathrm{CO}\left(\mathrm{H}_{2} / \mathrm{CO}=4\right)$. The temperature was then linearly increased at a rate of $10{ }^{\circ} \mathrm{C} \mathrm{min}^{-1}$ to $450{ }^{\circ} \mathrm{C}$. The effluent stream was monitored using the MS.

The CO TPD experiments were performed by dosing the catalyst sample at RT with 5 $\mathrm{mL}$ of a $5 \% \mathrm{CO} / \mathrm{He}$ mixture until saturation was achieved. Saturation was typically achieved within $4-8$ doses. In flowing $\mathrm{He}$, the temperature was then linearly increased at $30{ }^{\circ} \mathrm{C} \mathrm{min}^{-1}$ to $800{ }^{\circ} \mathrm{C}$. The effluent stream was monitored using the MS and the TCD. The CO TPD spectra consisted of multiple peaks; therefore the TPD spectra had to be deconvolved. The deconvolution was performed using CasaXPS, a commercially available peak deconvolution software package that is typically used to analyze X-ray photoelectron spectra. The TPD spectra were deconvolved using a non-linear least squares method employing Gaussian distributions. The primary constraint imposed during fitting was that the relative intensities (i.e., relative peak areas) of the different peaks were held constant for each spectrum (i.e., the relative amounts of 
the different $\mathrm{CO}$ adsorption sites on the catalyst surface should remain constant regardless of heating rate).

The $\mathrm{CO}$ adsorption energies were determined from the CO TPD spectra $(\mathrm{m} / \mathrm{z}=28)$ using the heating rate variation method $[34,35]$. The rate of desorption of molecules on a catalyst surface, $r_{d e s}$, is described by the Polanyi-Wigner equation [34]:

$$
r_{d e s}=-\frac{d \Theta}{d t}=v_{n} \exp \left(-\frac{\Delta E_{d e s}^{P W}}{R T}\right) \Theta^{n} \quad \text { Eqn. 5 }
$$

where $t$ is time, $\Theta$ is the surface coverage, $v_{n}$ is the frequency factor, $T$ is temperature, $R$ is the ideal gas constant, $\Delta E_{d e s}^{P W}$ is the activation energy of desorption, and $n$ is the desorption rate order. Performing some basic calculus and assuming first order desorption $(\mathrm{n}=1)$, Equation 5 can be written in the following form:

$$
\ln \frac{T_{\max }^{2}}{\beta}=\frac{\Delta E_{d e s}}{R T_{\max }}+\ln \frac{\Delta E_{d e s}}{v_{1} R}
$$

where $T_{\max }$ is the temperature at which the maximum desorption rate occurs and $\beta$ is the heating rate. By plotting $\ln \left(T_{\max }^{2} / \beta\right)$ vs. $1 / T_{\max }$ for a series of $\beta$ values, $\Delta E_{\text {des }}$ was determined from the slope of the line. The linear regression was performed using commercially-available SPSS Statistics software. The $\beta$ values used in this study ranged from 4 to $40{ }^{\circ} \mathrm{C} \mathrm{min}^{-1}$.

To probe $\mathrm{CO}$ dissociation and hydrogenation over $\mathrm{Mo}_{2} \mathrm{C}$ and $\mathrm{Mo}_{2} \mathrm{~N}$, an experimental sequence consisting of 4 steps (i.e., pretreatment, $\mathrm{CO}$ exposure, TPD, and $\mathrm{H}_{2}$ TPRxn) was performed, as shown in Fig. 1. Step 1 (pretreatment) was performed as described above in Section 2.1. The catalyst sample was then cooled down in Ar to a specified temperature. Step 2 (CO exposure) involved holding the catalyst at this temperature for $1 \mathrm{~h}$ while exposing it to a flowing mixture of $10 \% \mathrm{CO} / \mathrm{Ar}$, so that $\mathrm{CO}$ can associatively and dissociatively adsorb to the 
catalyst surface. For comparison, blank runs were also performed in which the catalyst sample was not exposed to $\mathrm{CO}$ (i.e., the sample was just held at the specified temperature for $1 \mathrm{~h}$ in flowing Ar). After Step 2, the catalyst was cooled to RT in Ar. Step 3 (TPD) involved increasing the temperature to $500{ }^{\circ} \mathrm{C}$ at a ramp rate of $20{ }^{\circ} \mathrm{C} \mathrm{min}^{-1}$ in flowing Ar. Based on the findings of St. Clair et al. [36], the maximum temperature of $500{ }^{\circ} \mathrm{C}$ was chosen to ensure desorption of all molecular $\mathrm{CO}$ and to minimize recombination of carbon and oxygen from dissociated CO. St. Clair reported recombination of $\mathrm{C}$ and $\mathrm{O}$ over $\mathrm{Mo}_{2} \mathrm{C}$ catalysts at temperatures above $500{ }^{\circ} \mathrm{C}$ [36]. The final temperature was held for 10 min prior to cooling the sample back to RT. The goal of Step 3 was to desorb the associatively adsorbed CO, leaving only adsorbed carbon and oxygen from $\mathrm{CO}$ dissociation on the catalyst surface. To explore the impact of molecularly adsorbed CO, experiments were also performed in which Step 3 was bypassed. In this case, it is assumed that molecular $\mathrm{CO}$ and adsorbed carbon and oxygen remain on the catalyst surface. Lastly, in Step 4 $\left(\mathrm{H}_{2}\right.$ TPRxn), the sample was exposed to a mixture of $10 \% \mathrm{H}_{2} / \mathrm{Ar}$ and the temperature was linearly increased at $20^{\circ} \mathrm{C} \min ^{-1}$ to a final temperature of $500{ }^{\circ} \mathrm{C}$. The goal was to hydrogenate the adsorbed carbon present from $\mathrm{CO}$ dissociation. The MS was used to monitor products in the effluent stream during all steps of the experiment.

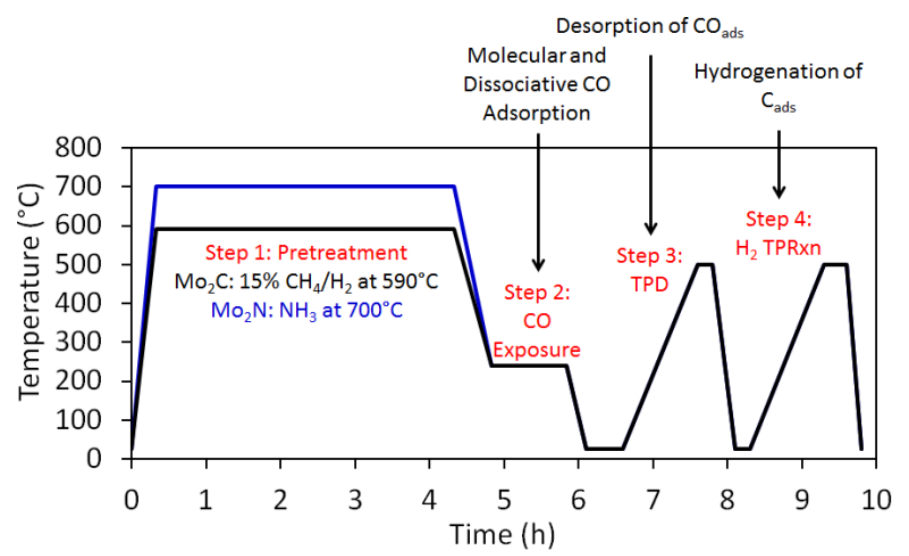

Fig. 1. Experimental sequence used to investigate $\mathrm{CO}$ dissociation and hydrogenation over $\mathrm{Mo}_{2} \mathrm{C}$ and $\mathrm{Mo}_{2} \mathrm{~N}$. 


\section{Results and Discussion}

\subsection{Materials Characterization}

X-ray diffraction patterns for the passivated carbide and nitride catalysts are shown in Fig. 2. Peaks attributable to the oxide precursors were not observed, suggesting that complete bulk carburization or nitridation of the starting materials was achieved. Except for the $\mathrm{Mo}_{2} \mathrm{C}$ and $\mathrm{W}_{2} \mathrm{C}$ catalysts, crystallites for all of the carbides and nitrides were fcc. For NbN, the small peaks at $2 \theta$ of $\sim 31^{\circ}, \sim 46^{\circ}$, and $\sim 62^{\circ}$ correspond to the hexagonal phase of $\mathrm{NbN}$ that can be formed under synthesis conditions similar to those used in this work [37]. The $\mathrm{W}_{2} \mathrm{C}$ catalyst had an orthorhombic (distorted hexagonal close packed) structure while the crystalline structure of the $\mathrm{Mo}_{2} \mathrm{C}$ catalyst was consistent with a mixture of $\alpha-\mathrm{MoC}_{1-\mathrm{x}}(\mathrm{fcc})$ and $\beta-\mathrm{Mo}_{2} \mathrm{C}$ (orthorhombic). This multi-phase $\mathrm{Mo}_{2} \mathrm{C}$ material has been produced previously in our research group [14, 26, 27] and was found to have a surface area twice that of $\beta-\mathrm{Mo}_{2} \mathrm{C}$. It should be noted that modifying synthesis conditions to maximize the surface areas was not a focus of this research.
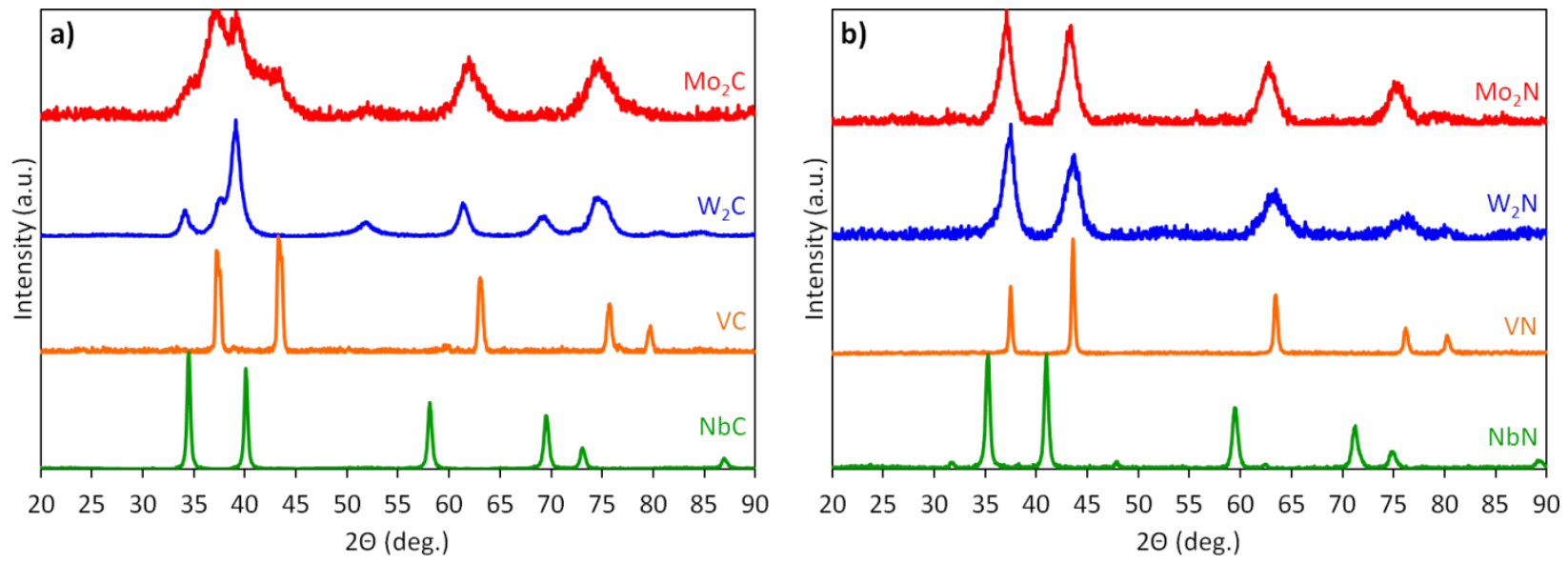

Fig. 2. X-ray diffraction patterns for the passivated (a) carbide and (b) nitride catalysts.

Results from surface area and $\mathrm{CO}$ chemisorption analysis are given in Table 1. The carbides and nitrides of Mo and $\mathrm{W}$ exhibited the highest $\mathrm{CO}$ uptakes and $\mathrm{CO}$ site densities. The $\mathrm{VN}$ and $\mathrm{NbN}$ catalysts exhibited $\mathrm{CO}$ site densities 4-5 times lower than those of the Mo and $\mathrm{W}$ carbides and nitrides. Differences have been reported previously, and may be due to carbon or 
oxygen impurities on the catalyst surface or varying degrees of surface carburization/nitridation $[38,39]$. The $\mathrm{CO}$ uptakes for $\mathrm{VC}$ and $\mathrm{NbC}$ were below the detection limit of the instrument $(\sim 1$ $\mu \mathrm{mol} \mathrm{g}{ }^{-1}$ ), thus CO site densities could not be calculated.

Table 1. Surface areas, CO uptakes, and site densities for the pretreated carbide and nitride catalysts.

\begin{tabular}{|c|c|c|c|}
\hline Catalyst & $\begin{array}{c}\text { Surface Area } \\
\left(\mathbf{m}^{\mathbf{2}} \mathbf{g}^{-\mathbf{1}}\right)\end{array}$ & $\begin{array}{c}\text { CO Uptake }^{\mathbf{a}} \\
\left(\boldsymbol{\mu} \mathbf{m o l ~ g}^{-\mathbf{1}}\right)\end{array}$ & $\begin{array}{c}\text { CO Site Density }^{\mathbf{b}} \\
\left(\mathbf{m o l e c u l e s ~}^{\mathbf{- 2}} \mathbf{x} \mathbf{1 0}^{\mathbf{1 8}}\right)\end{array}$ \\
\hline $\mathrm{Mo}_{2} \mathrm{C}$ & 106 & 268 & 1.52 \\
\hline $\mathrm{Mo}_{2} \mathrm{~N}$ & 154 & 307 & 1.20 \\
\hline $\mathrm{W}_{2} \mathrm{C}$ & 36 & 74 & 1.24 \\
\hline $\mathrm{W}_{2} \mathrm{~N}$ & 82 & 109 & 0.80 \\
\hline $\mathrm{VC}$ & 9 & $<1$ & -- \\
\hline $\mathrm{VN}$ & 28 & 8 & 0.27 \\
\hline $\mathrm{NbC}$ & 10 & $<1$ & -- \\
\hline $\mathrm{NbN}$ & 47 & 11 & 0.14 \\
\hline
\end{tabular}

${ }^{\mathrm{a}} \mathrm{CO}$ uptake calculated from $\mathrm{CO}$ pulse chemisorption performed at room temperature.

${ }^{\mathrm{b}} \mathrm{CO}$ site density calculated from BET surface area and $\mathrm{CO}$ uptake for the pretreated catalysts.

\subsection{Fischer-Tropsch Synthesis}

Arrhenius plots of the gravimetric FTS product formation rates, excluding $\mathrm{CO}_{2}$, for the carbide and nitride catalysts are shown in Fig. 3a. For the lower temperature range, only the $\mathrm{Mo}_{2} \mathrm{C}$ and $\mathrm{W}_{2} \mathrm{C}$ catalysts exhibited measureable product formation rates. On a gravimetric basis, the most active catalyst was $\mathrm{Mo}_{2} \mathrm{C}$. This result is not surprising as $\mathrm{Mo}_{2} \mathrm{C}$ exhibited high $\mathrm{CO}$ uptakes, indicating that there is a high density of sites for $\mathrm{CO}$ to adsorb and potentially react. The $\mathrm{Mo}_{2} \mathrm{C}$ catalyst was not tested at temperatures above $300{ }^{\circ} \mathrm{C}$ as it became very difficult to maintain control of the temperature due to the exothermic nature of the reaction. The $\mathrm{VC}$ and $\mathrm{NbC}$ catalysts were the least active catalysts tested; they did not exhibit measureable $\mathrm{CO}$ conversions under the conditions employed.

It should be noted that the VN catalyst exhibited behavior that differed from that for the other catalysts. In particular, the reaction rate for the VN catalyst did not increase with increasing temperature above $300{ }^{\circ} \mathrm{C}$. This result could be due to a change in the catalyst's 
structure, functional properties (e.g., deactivation, reaction pathway, or kinetics), or diffusion limitations. To assess the impact of diffusion effects for the VN catalyst as well as the other materials, the Weiss-Prater criterion, $N_{W-P}$, was evaluated [40]. Assuming either $\mathrm{CO}$ or $\mathrm{H}_{2}$ as the limiting reactant, the $N_{W-P}$ was determined to be less than $1 \times 10^{-3}$ for all of the catalysts at 320 ${ }^{\circ} \mathrm{C}$, which is much less than 0.3 indicating that the reaction is not diffusion limited under these conditions. The cause of the behavior observed for $\mathrm{VN}$ is unclear. We speculate that the catalyst deactivated, but additional investigation is needed to evaluate this possibility.
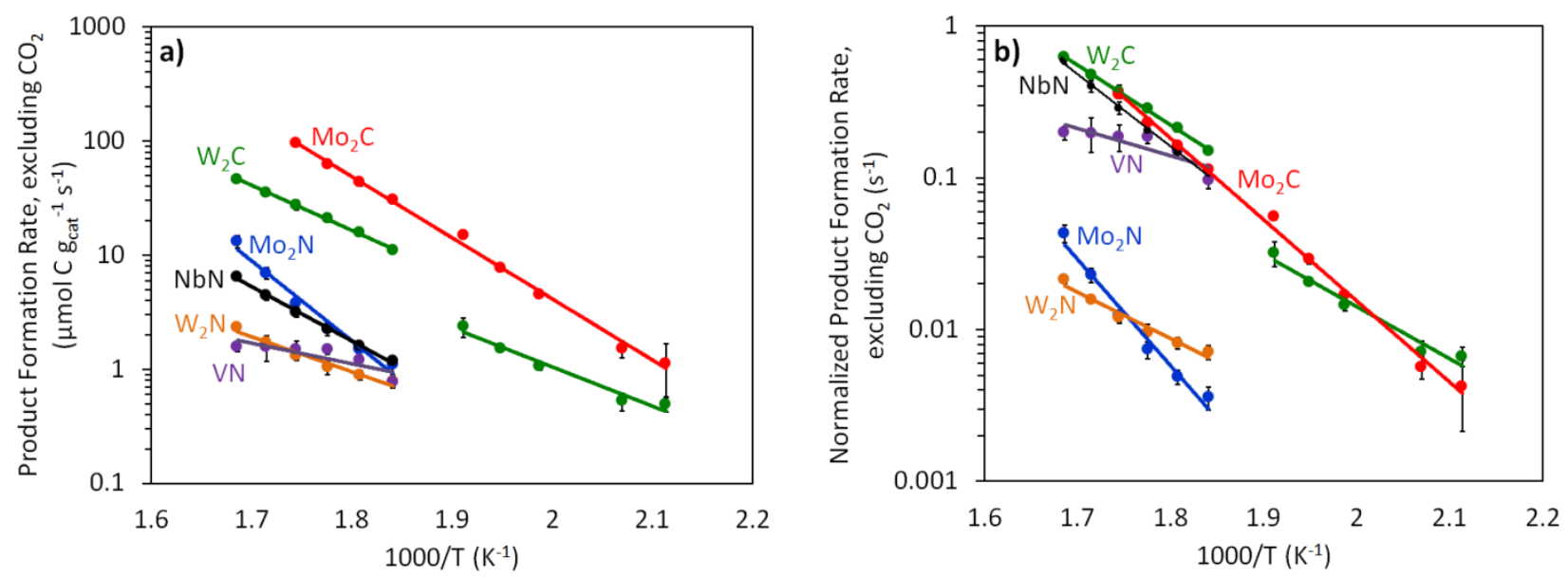

Fig. 3. Arrhenius plots of the product formation rates on a $\mathrm{C}_{1}$ basis (excluding $\mathrm{CO}_{2}$ ) for the carbide and nitride catalysts on (a) a gravimetric basis and (b) normalized by the $\mathrm{CO}$ uptakes.

To estimate the intrinsic activity of the catalysts, the product formation rates were normalized by the $\mathrm{CO}$ uptakes (Fig. 3b). On a $\mathrm{CO}$ normalized basis, the $\mathrm{Mo}_{2} \mathrm{C}, \mathrm{W}_{2} \mathrm{C}$, VN, and $\mathrm{NbN}$ catalysts exhibited similar product formation rates. Rates for the $\mathrm{Mo}_{2} \mathrm{~N}$ and $\mathrm{W}_{2} \mathrm{~N}$ catalysts were more than an order of magnitude lower. The activity trend for these materials is as follows: $\mathrm{Mo}_{2} \mathrm{C} \sim \mathrm{W}_{2} \mathrm{C} \sim \mathrm{VN} \sim \mathrm{NbN}>\mathrm{Mo}_{2} \mathrm{~N}, \mathrm{~W}_{2} \mathrm{~N}>\mathrm{VC}, \mathrm{NbC}$. Based on these results, there appears to be a significant difference in FTS activity for carbides and nitrides of the same parent metal. For example, the normalized rate for the $\mathrm{Mo}_{2} \mathrm{C}$ catalyst was $0.36 \mathrm{~s}^{-1}$ at $300{ }^{\circ} \mathrm{C}$ while the rate for $\mathrm{Mo}_{2} \mathrm{~N}$ was only $0.04 \mathrm{~s}^{-1}$, even though these materials exhibited similar surface areas, $\mathrm{CO}$ uptakes, and $\mathrm{CO}$ site densities. Performance differences for carbides and nitrides of the same metal have 
also been reported for acetone condensation [41] and n-butane hydrogenolysis, dehydrogenation, and isomerization [30]. For acetone conversion, the $\mathrm{Mo}_{2} \mathrm{~N}$ catalyst favored condensation producing mesityl oxide while the $\mathrm{Mo}_{2} \mathrm{C}$ catalyst favored hydrogenation to isopropanol, followed by subsequent dehydration to propylene [41].

Using the normalized rates shown in Fig. $3 b$, the activity of the carbides and nitrides can be compared to typical Fischer-Tropsch catalysts containing, for example, Co. Based on a review by Ribeiro et al., the average $\mathrm{CO}$ hydrogenation turnover frequency for a series of supported Co catalysts was $0.017 \pm 0.014 \mathrm{~s}^{-1}$ at $200{ }^{\circ} \mathrm{C}, 10 \mathrm{~atm}$, and $\mathrm{H}_{2} / \mathrm{CO}=2$ [42]. At $200{ }^{\circ} \mathrm{C}$, the $\mathrm{CO}$ normalized rate observed for the $\mathrm{Mo}_{2} \mathrm{C}$ catalyst $\left(0.004 \pm 0.002 \mathrm{~s}^{-1}\right)$ was $\sim 4$ times lower than the average value reported for supported Co catalysts. This result is consistent with the report by Shou et al., which indicated that while $\mathrm{Mo}_{2} \mathrm{C}$ catalysts are capable of relatively high turnovers, a low apparent activity is typically observed due to an extremely low surface coverage of reaction intermediates [21].

Table 2. Fischer-Tropsch Synthesis apparent activation energies for the carbide and nitride catalysts.

\begin{tabular}{|c|c|c|}
\hline & \multicolumn{2}{|c|}{ 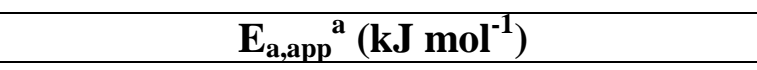 } \\
\hline & & \\
\hline Catalyst & $200-250{ }^{\circ} \mathrm{C}$ & $270-320{ }^{\circ} \mathrm{C}$ \\
\hline $\mathrm{Mo}_{2} \mathrm{C}$ & 107 & 98 \\
\hline $\mathrm{Mo}_{2} \mathrm{~N}$ & -- & 134 \\
\hline $\mathrm{W}_{2} \mathrm{C}$ & 66 & 76 \\
\hline $\mathrm{W}_{2} \mathrm{~N}$ & -- & 59 \\
\hline VN & -- & $85^{b}$ \\
\hline $\mathrm{NbN}$ & -- & 91 \\
\hline
\end{tabular}

${ }^{\mathrm{a}} \mathrm{E}_{\mathrm{a} \text {,app }}$ was calculated from product formation rates excluding $\mathrm{CO}_{2}$.

${ }^{b} \mathrm{E}_{\mathrm{a}, \text { app }}$ for $\mathrm{VN}$ was calculated from only the first three points $\left(270^{\circ} \mathrm{C}, 280{ }^{\circ} \mathrm{C}\right.$, and $\left.290{ }^{\circ} \mathrm{C}\right)$.

The apparent activation energies $\left(E_{a, a p p}\right)$ for the carbide and nitride catalysts are given in Table 2. For the temperature range $270-320^{\circ} \mathrm{C}$, the $\mathrm{Mo}_{2} \mathrm{~N}$ catalyst exhibited the highest $E_{a, a p p}$ of $134 \mathrm{~kJ} \mathrm{~mol}^{-1}$, while the $\mathrm{W}_{2} \mathrm{C}$ and $\mathrm{W}_{2} \mathrm{~N}$ catalysts exhibited the lowest values, $76 \mathrm{~kJ} \mathrm{~mol}^{-1}$ and 59 
$\mathrm{kJ} \mathrm{mol}^{-1}$, respectively. The $\mathrm{Mo}_{2} \mathrm{C}$ catalyst exhibited an activation energy over this temperature range that was $36 \mathrm{~kJ} \mathrm{~mol}^{-1}$ lower than that for the $\mathrm{Mo}_{2} \mathrm{~N}$ catalyst, consistent with the observed differences in TOF. Activation energies for $\mathrm{CO}$ hydrogenation over the $\mathrm{Mo}_{2} \mathrm{C}$ and $\mathrm{Mo}_{2} \mathrm{~N}$ catalysts reported in literature range from $60-170 \mathrm{~kJ} \mathrm{~mol}^{-1}$ depending upon reaction conditions and the products $[6,9]$. It should be noted that these reports employed $\mathrm{H}_{2}$ to activate the catalysts. The $E_{a, a p p}$ values for the $\mathrm{Mo}_{2} \mathrm{C}$ and $\mathrm{Mo}_{2} \mathrm{~N}$ catalysts examined in this study were within those reported ranges.

Table 3. Fischer-Tropsch Synthesis performance characteristics for the carbide and nitride catalysts at 25 bar and $\mathrm{H}_{2} / \mathrm{CO}=2$.

\begin{tabular}{|c|c|c|c|c|c|c|c|c|c|c|c|}
\hline \multirow[b]{2}{*}{ Catalyst } & \multirow[b]{2}{*}{$\begin{array}{c}\mathbf{T} \\
\left({ }^{\circ} \mathbf{C}\right)\end{array}$} & \multirow[b]{2}{*}{$\begin{array}{c}\text { CO } \\
\text { Conv. } \\
(\%)\end{array}$} & \multirow[b]{2}{*}{$\underset{\left(\mathbf{s}^{-1}\right)}{\text { TOF }}$} & \multicolumn{5}{|c|}{ Product Selectivity on $\mathrm{C}_{1}$ Basis (\%) } & \multicolumn{2}{|c|}{$\boldsymbol{R}_{n}$} & \multirow[b]{2}{*}{$\alpha$} \\
\hline & & & & $\mathrm{CH}_{4}$ & $\mathbf{C}_{2}-\mathbf{C}_{4}$ & $\mathrm{C}_{5+}$ & Alcohols & $\mathrm{CO}_{2}$ & $\mathbf{C}_{2}$ & $\mathbf{C}_{3}$ & \\
\hline \multirow{2}{*}{$\mathrm{Mo}_{2} \mathrm{C}$} & 200 & 0.7 & 0.004 & 27.7 & 31.2 & 9.7 & 17.2 & 14.2 & 0.23 & 1.02 & 0.45 \\
\hline & 290 & 10.5 & 0.36 & 35.1 & 26.5 & 1.7 & 0.7 & 36.0 & 0.03 & 0.24 & 0.31 \\
\hline $\mathrm{Mo}_{2} \mathrm{~N}$ & 290 & 2.1 & 0.014 & 31.9 & 20.7 & 1.6 & 0.7 & 45.1 & 0.16 & 1.03 & 0.33 \\
\hline \multirow{2}{*}{$\mathrm{W}_{2} \mathrm{C}$} & 200 & 0.3 & 0.007 & 27.4 & 36.4 & 18.4 & 0.9 & 16.9 & 0.55 & 1.4 & 0.50 \\
\hline & 290 & 2.9 & 0.35 & 41.5 & 33.4 & 3.6 & 3.3 & 18.2 & 0.06 & 0.50 & 0.35 \\
\hline $\mathrm{W}_{2} \mathrm{~N}$ & 290 & 0.6 & 0.011 & 51.7 & 24.8 & 4.1 & 2.3 & 17.1 & 0.46 & 1.81 & 0.43 \\
\hline VN & 290 & 1.7 & 0.20 & 58.5 & 29.0 & 2.1 & 2.0 & 8.4 & 0.18 & 1.30 & 0.35 \\
\hline $\mathrm{NbN}$ & 290 & 2.4 & 0.22 & 65.7 & 23.0 & 1.3 & 2.1 & 7.9 & 0.06 & 0.74 & 0.31 \\
\hline
\end{tabular}

The selectivities of the carbide and nitride catalysts are compared in Table 3 . At $290^{\circ} \mathrm{C}$, $\mathrm{CO}$ conversions for all of the catalysts were similar, allowing for an equitable comparison as the extent of conversion can affect selectivity [33]. The primary products were hydrocarbons and $\mathrm{CO}_{2}$. The hydrocarbon fraction was dominated by light products, $\mathrm{C}_{1}-\mathrm{C}_{4}\left(>90 \%\right.$ on a $\mathrm{C}_{1}$ basis $)$, with selectivities to higher hydrocarbons $\left(\mathrm{C}_{5+}\right)$ between 2 and $5 \%$. Only a small percentage of alcohols were produced; however, it should be noted that high temperatures are not favorable for alcohol formation. The product selectivities were affected significantly by temperature. At 200 ${ }^{\circ} \mathrm{C}$, the $\mathrm{Mo}_{2} \mathrm{C}$ catalyst produced $68 \%$ hydrocarbons, $14 \% \mathrm{CO}_{2}$, and $18 \%$ alcohols compared to 
$63 \%$ hydrocarbons, $36 \% \mathrm{CO}_{2}$, and $1 \%$ alcohols at $290{ }^{\circ} \mathrm{C}$. Methanol and ethanol were the only alcohols produced, with ethanol being the more favored product at $290^{\circ} \mathrm{C}$. The $\mathrm{VN}$ and $\mathrm{NbN}$ catalysts exhibited the highest selectivities to hydrocarbons while the $\mathrm{Mo}_{2} \mathrm{C}$ and $\mathrm{Mo}_{2} \mathrm{~N}$ catalysts exhibited the lowest selectivities to hydrocarbons at $290{ }^{\circ} \mathrm{C}$. Based on the observed production of $\mathrm{CO}_{2}$, all of the catalysts appeared to be active for water-gas shift (WGS). The trend in terms of $\mathrm{CO}_{2}$ selectivity was as follows: $\mathrm{Mo}_{2} \mathrm{C} \sim \mathrm{Mo}_{2} \mathrm{~N}>\mathrm{W}_{2} \mathrm{C} \sim \mathrm{W}_{2} \mathrm{~N}>\mathrm{VN} \sim \mathrm{NbN}$.

The olefin selectivities, $R_{n}$, for all of the catalysts followed the same trend as a function of carbon number. The ratios were typically lowest for $\mathrm{C}_{2}$ and highest for $\mathrm{C}_{3}$. The $\mathrm{W}_{2} \mathrm{~N}$ catalyst exhibited the highest $R_{n}$ while the $\mathrm{Mo}_{2} \mathrm{C}$ catalyst exhibited the lowest $R_{n}$. It is not surprising that the $\mathrm{Mo}_{2} \mathrm{C}$ catalyst favored saturated hydrocarbons as it has been reported to be active for a variety of hydrogenation reactions [43-45]. The chain growth probabilities, $\alpha$, for each catalyst are listed in Table 3. At $290{ }^{\circ} \mathrm{C}$, the highest $\alpha(0.43)$ was observed for $\mathrm{W}_{2} \mathrm{~N}$ and the lowest $\alpha$ (0.31) was observed for $\mathrm{NbN}$ and $\mathrm{Mo}_{2} \mathrm{C}$. The $\alpha$ values for the other catalysts were all within error of each other.

To directly compare the carbide and nitride catalysts to typical FTS catalysts, commercial $\mathrm{Fe} / \mathrm{SiO}_{2}$ and $\mathrm{Co} / \mathrm{Al}_{2} \mathrm{O}_{3}$ catalysts were obtained and evaluated in the fixed bed FTS reactor. At $230{ }^{\circ} \mathrm{C}, 25$ bar, $\mathrm{H}_{2} / \mathrm{CO}=2$, and $\mathrm{X}_{\mathrm{CO}}<10 \%$, the hydrocarbon selectivities on a $\mathrm{C}_{1}$ basis to $\mathrm{C}_{5+}$ hydrocarbons were $37 \%$ and $41 \%$ for the $\mathrm{Fe} / \mathrm{SiO}_{2}$ and $\mathrm{Co} / \mathrm{Al}_{2} \mathrm{O}_{3}$ catalysts, respectively. Under the same conditions, the $\mathrm{C}_{5+}$ hydrocarbon selectivity for the $\mathrm{Mo}_{2} \mathrm{C}$ catalyst was $\sim 10 \%$. The ASF $\alpha$ values for these materials were $0.65,0.66$, and 0.43 for the $\mathrm{Fe} / \mathrm{SiO}_{2}, \mathrm{Co} / \mathrm{Al}_{2} \mathrm{O}_{3}$, and $\mathrm{Mo}_{2} \mathrm{C}$ catalysts, respectively. These results indicate that $\mathrm{C}-\mathrm{C}$ coupling occurs much more readily over the $\mathrm{Fe}$ and $\mathrm{Co}$ based catalysts than over the $\mathrm{Mo}_{2} \mathrm{C}$ catalyst. It should be noted that the $\mathrm{Fe}$ and $\mathrm{Co}$ based catalysts have been tuned to achieve high selectivity to $\mathrm{C}_{5+}$ products, as compared to the 
unoptimized $\mathrm{Mo}_{2} \mathrm{C}$ material. The $\mathrm{C}-\mathrm{C}$ coupling is affected by a number of factors: reaction pathway (i.e., FTS mechanism), carbon mobility on the catalyst surface, and $\mathrm{CO}, \mathrm{H}_{2}$ and $\mathrm{CH}_{\mathrm{x}}$ coverages under reaction conditions [46-48]. Overall, it appears that the selectivities of the carbides and nitrides lie in between those of $\mathrm{Ni}$ (which favors methane) and Fe (which favors long-chain hydrocarbons, but also produces $\mathrm{CO}_{2}$ through WGS).

\subsection{Temperature Programmed Desorption and Reaction Experiments}

The TPD and TPRxn experiments were performed to probe for differences that could explain differences in the FTS TOFs exhibited by carbides and nitrides of the same parent metal. The $\mathrm{Mo}_{2} \mathrm{C}$ and $\mathrm{Mo}_{2} \mathrm{~N}$ catalysts were investigated for these experiments. The reactivities were first explored using a $\mathrm{H}_{2}-\mathrm{CO}$ TPRxn. The MS intensity $\left(\mathrm{m} / \mathrm{z}=15, \mathrm{CH}_{3}\right.$ fragments) during the TPRxn is shown in Fig. 4. The $\mathrm{Mo}_{2} \mathrm{C}$ catalyst exhibited a light off temperature for $\mathrm{CO}$ hydrogenation of approximately $200{ }^{\circ} \mathrm{C}$ while the $\mathrm{Mo}_{2} \mathrm{~N}$ catalyst did not begin to produce $\mathrm{CH}_{4}$ until $300-350{ }^{\circ} \mathrm{C}$. This result is in accordance with the flow reactor experiments as the $\mathrm{Mo}_{2} \mathrm{~N}$ catalyst was not active over the lower temperature range $\left(200-250{ }^{\circ} \mathrm{C}\right)$. The higher light off temperature is consistent with a higher activation barrier for $\mathrm{CO}$ hydrogenation over the $\mathrm{Mo}_{2} \mathrm{~N}$ catalyst compared to the $\mathrm{Mo}_{2} \mathrm{C}$ catalyst, and a higher observed apparent activation energy (Table 2). 


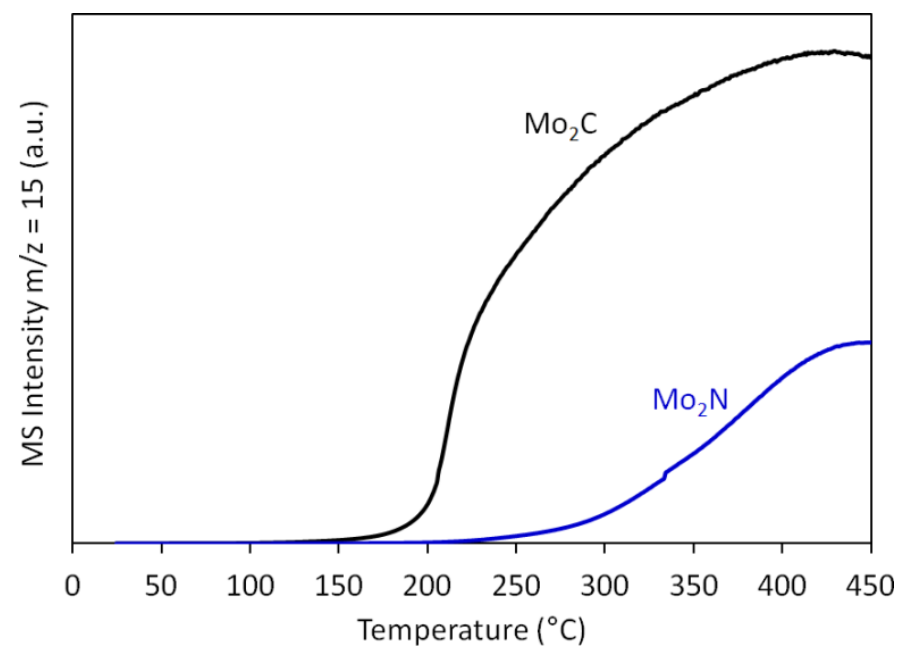

Fig. 4. Production of $\mathrm{CH}_{3}$ fragments $(\mathrm{m} / \mathrm{z}=15)$ during $\mathrm{H}_{2}-\mathrm{CO}$ TPRxn over the $\mathrm{Mo}_{2} \mathrm{C}$ and $\mathrm{Mo}_{2} \mathrm{~N}$ catalysts.

The apparent activation energy is most significantly affected by the elementary step with the slowest forward rate, i.e. the rate-limiting step. The rate-limiting step for FTS is often reported to be either (i) adsorption and dissociation of $\mathrm{CO}$ or (ii) the hydrogenation of carbon species $[33,49,50]$. To investigate the first of these proposed rate-limiting steps, CO TPD experiments were performed (Fig. 5). Both the $\mathrm{Mo}_{2} \mathrm{C}$ and $\mathrm{Mo}_{2} \mathrm{~N}$ catalysts exhibited similar $\mathrm{CO}$ TPD spectra; there was a broad desorption peak centered at $\sim 100{ }^{\circ} \mathrm{C}$. The similarity between these spectra suggested that the materials possessed similar molecular $\mathrm{CO}$ adsorption energies. However, a significant amount of $\mathrm{CO}_{2}$ was also produced during TPD over the $\mathrm{Mo}_{2} \mathrm{C}$ catalyst (Fig. S2), indicating that $\mathrm{Mo}_{2} \mathrm{C}$ catalyzed the disproportionation of $\mathrm{CO}$ (Boudouard reaction). A negligible amount of $\mathrm{CO}_{2}$ was observed over the $\mathrm{Mo}_{2} \mathrm{~N}$ catalyst during the TPD. 

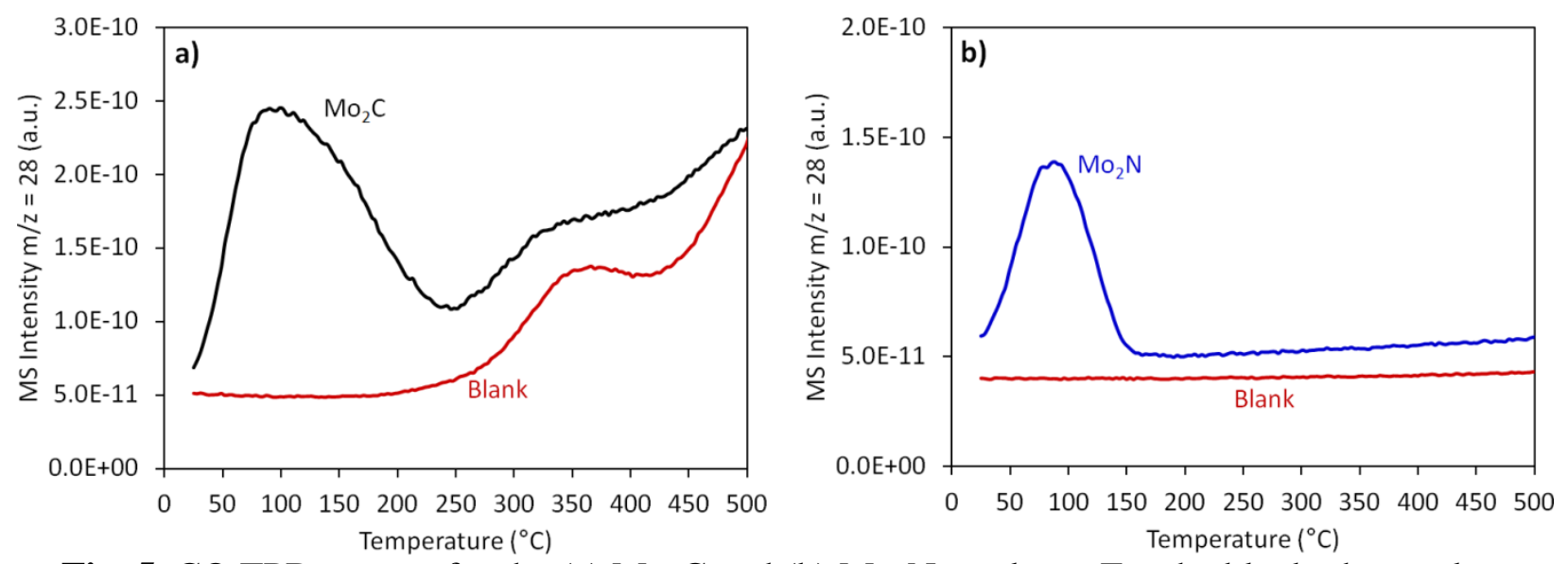

Fig. 5. $\mathrm{CO}$ TPD spectra for the (a) $\mathrm{Mo}_{2} \mathrm{C}$ and (b) $\mathrm{Mo}_{2} \mathrm{~N}$ catalysts. For the blank, the catalyst surface was not exposed to $\mathrm{CO}$. The heating rate was $30^{\circ} \mathrm{C} / \mathrm{min}$.

The molecular $\mathrm{CO}$ adsorption energies (i.e., the activation energy for desorption, $\Delta E_{d e s}$ ) were experimentally determined for the $\mathrm{Mo}_{2} \mathrm{C}$ catalyst using a heating rate variation method [34, 35]. To do so, the broad desorption peak was fit to 4 separate $\mathrm{CO}$ desorption peaks. The deconvoluted CO TPD spectra for the $\mathrm{Mo}_{2} \mathrm{C}$ catalyst at the highest $\left(40{ }^{\circ} \mathrm{C} \mathrm{min}{ }^{-1}\right.$ ) and lowest (4 ${ }^{\circ} \mathrm{C} \min ^{-1}$ ) heating rates are shown in Fig. 6. The temperature at which the maximum desorption rate occurs, $T_{\max }$, was determined for each peak, and the $\mathrm{CO}$ desorption energies were calculated by plotting $\ln \left(T_{\max }^{2} / \beta\right)$ vs. $1 / T_{\max }$ (Fig. S3 and Table S2). The desorption energies were 91, 103, 126 , and $148 \mathrm{~kJ} \mathrm{~mol}^{-1}$ for peaks $1-4$, respectively. These values are similar to those reported by St. Clair $\left(93-115 \mathrm{~kJ} \mathrm{~mol}^{-1}\right)$, determined via CO TPD from a $\mathrm{Mo}_{2} \mathrm{C}$ single crystal, $\alpha-\mathrm{Mo}_{2} \mathrm{C}$ (0001) [36].
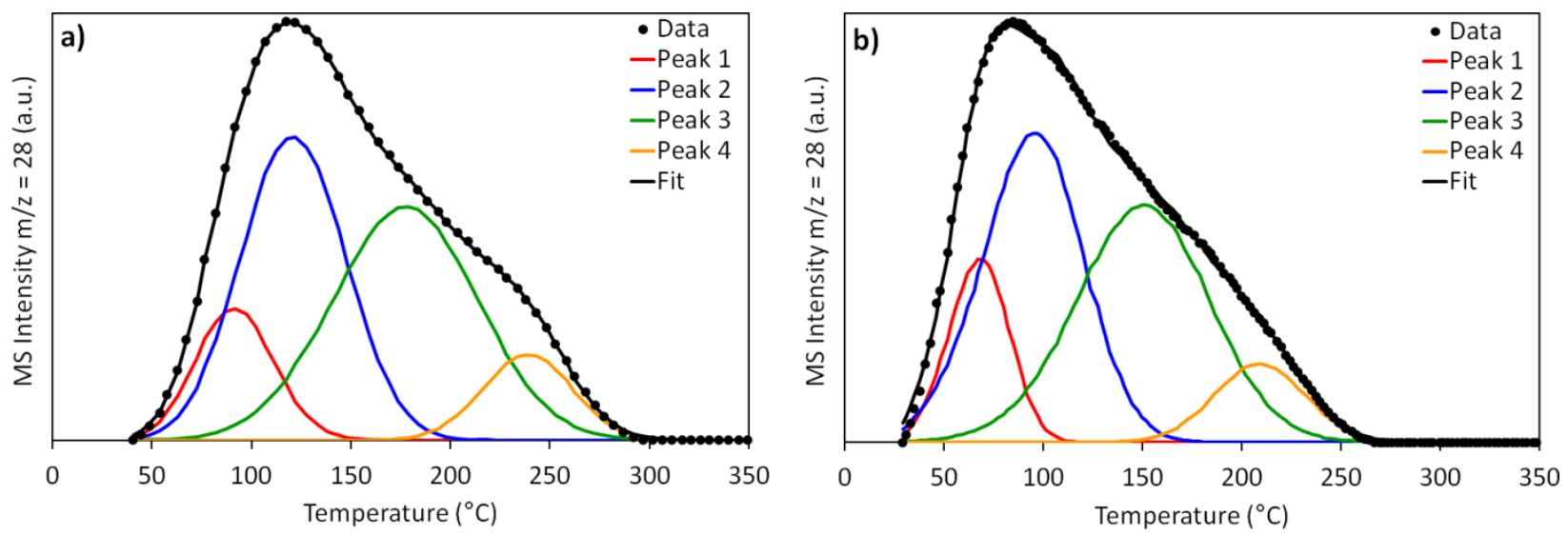
Fig. 6. Deconvoluted CO TPD spectra for the $\mathrm{Mo}_{2} \mathrm{C}$ catalyst at heating rates of (a) $40{ }^{\circ} \mathrm{C} / \mathrm{min}$ and (b) $4{ }^{\circ} \mathrm{C} / \mathrm{min}$.

$\mathrm{CO}$ dissociation and hydrogenation were investigated over the $\mathrm{Mo}_{2} \mathrm{C}$ and $\mathrm{Mo}_{2} \mathrm{~N}$ catalysts using the four step experimental sequence shown in Fig. 1. A thorough description of the sequence is provided in Section 2.4, but briefly, this sequence was used to probe: (i) the effect of $\mathrm{CO}$ exposure temperature on the extent of $\mathrm{CO}$ dissociation and subsequent hydrogenation and (ii) the effect of molecularly vs. dissociatively adsorbed CO on FTS products. In particular, Step 3 allows us to selectively remove molecularly adsorbed $\mathrm{CO}$, and thus interrogate its role in the FTS mechanism over these materials. Fig. 7 shows the MS intensity for $\mathrm{CO}(\mathrm{m} / \mathrm{z}=28)$ during the Ar TPD step (Step 3) over the $\mathrm{Mo}_{2} \mathrm{C}$ and $\mathrm{Mo}_{2} \mathrm{~N}$ catalysts as a function of the $\mathrm{CO}$ exposure temperature during Step 2. As the $\mathrm{CO}$ exposure temperature increased over the $\mathrm{Mo}_{2} \mathrm{C}$ catalyst, the intensity of the $\mathrm{CO}$ desorption peak decreased and the peak shifted to higher temperatures. A similar shift, albeit to a lesser extent, was also observed for the $\mathrm{Mo}_{2} \mathrm{~N}$ catalyst, for which $\mathrm{CO}$ exposure temperatures of $240{ }^{\circ} \mathrm{C}$ and higher were used due to its lack of activity at lower temperatures. The shift in intensity and temperature may have been due to $\mathrm{CO}$ no longer occupying the adsorption sites with lower binding energies; the temperature for $\mathrm{CO}$ exposure was above the temperature at which $\mathrm{CO}$ desorbs from these sites. A similar shift in intensity and temperature was also observed for $\mathrm{CO}_{2}$ produced during the TPD experiments (Fig. S4). At the highest temperatures for $\mathrm{CO}$ exposure $\left(320^{\circ} \mathrm{C}\right.$ and $\left.340^{\circ} \mathrm{C}\right)$, there are $\mathrm{CO}$ desorption peaks present at temperatures above $350{ }^{\circ} \mathrm{C}$. These peaks may be due to the recombination of adsorbed carbon and oxygen produced during CO dissociation [36]. 

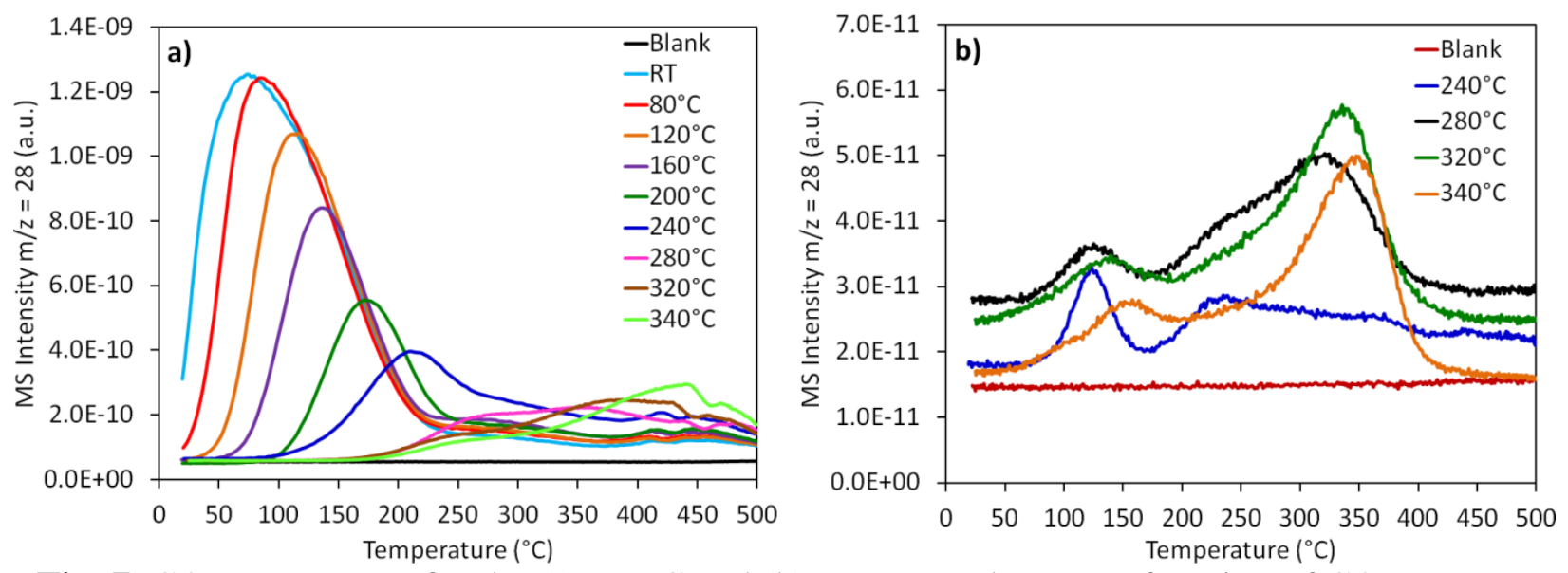

Fig. 7. $\mathrm{CO}$ TPD spectra for the (a) $\mathrm{Mo}_{2} \mathrm{C}$ and (b) $\mathrm{Mo}_{2} \mathrm{~N}$ catalysts as a function of $\mathrm{CO}$ exposure temperature. A blank spectrum is shown in which the catalyst was not exposed to CO.

The Ar TPD step (Step 3) is designed to remove molecularly adsorbed CO from the catalyst surface, leaving behind adsorbed carbon (from either direct $\mathrm{CO}$ dissociation (without $\mathrm{H}_{2}$ assistance) or disproportionation) for subsequent hydrogenation during the $\mathrm{H}_{2}$ TPRxn step (Step 4). Fig. 8 shows the MS intensity for $\mathrm{m} / \mathrm{z}=15\left(\mathrm{CH}_{3}\right.$ fragments) during the $\mathrm{H}_{2} \mathrm{TPRxn}$ step for the $\mathrm{Mo}_{2} \mathrm{C}$ and $\mathrm{Mo}_{2} \mathrm{~N}$ catalysts as a function of $\mathrm{CO}$ exposure temperature. For a $\mathrm{CO}$ exposure temperature of $240{ }^{\circ} \mathrm{C}$, a significant amount of $\mathrm{CH}_{4}$ was produced over the $\mathrm{Mo}_{2} \mathrm{C}$ surface compared to the blank (no $\mathrm{CO}$ exposure). The primary $\mathrm{CH}_{4}$ desorption peaks were centered at $\sim 450{ }^{\circ} \mathrm{C}$. As the $\mathrm{CO}$ exposure temperature increased, the intensity of the $\mathrm{CH}_{4}$ desorption peaks increased. This result suggests that higher exposure temperatures resulted in a higher concentration of adsorbed carbon. 

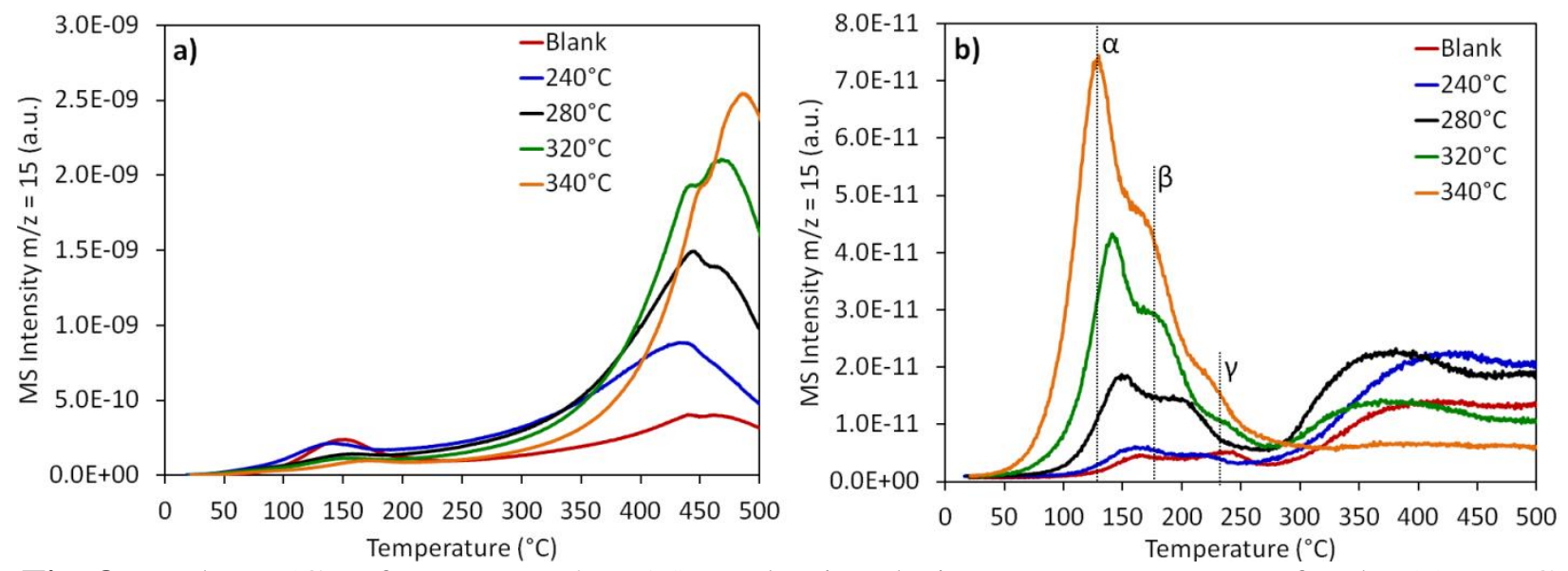

Fig. 8. Methane $\left(\mathrm{CH}_{3}\right.$ fragment, $\left.\mathrm{m} / \mathrm{z}=15\right)$ production during $\mathrm{H}_{2} \mathrm{TPRxn}$ spectra for the (a) $\mathrm{Mo}_{2} \mathrm{C}$ and (b) $\mathrm{Mo}_{2} \mathrm{~N}$ catalysts as a function of $\mathrm{CO}$ exposure temperature. A blank is also shown in which the catalyst was not exposed to $\mathrm{CO}$.

For the $\mathrm{Mo}_{2} \mathrm{~N}$ catalyst, the spectra for the sample exposed to $\mathrm{CO}$ at $240{ }^{\circ} \mathrm{C}$ and the blank were similar, suggesting that $\mathrm{CO}$ dissociation did not occur at this temperature. However, as the temperature for $\mathrm{CO}$ exposure was increased, three $\mathrm{CH}_{4}$ desorption peaks at $\sim 140{ }^{\circ} \mathrm{C}, \sim 180{ }^{\circ} \mathrm{C}$, and $\sim 220{ }^{\circ} \mathrm{C}$ were observed during TPRxn, and designated as $\alpha, \beta$, and $\gamma$, respectively. Similar to the $\mathrm{Mo}_{2} \mathrm{C}$ catalyst, the intensity of the $\mathrm{CH}_{4}$ desorption peaks increased as the $\mathrm{CO}$ exposure temperature was increased. Additionally, the peaks shifted towards lower temperatures with increasing $\mathrm{CO}$ exposure temperatures. The ratio of intensity of the $\alpha$ to the $\beta$ peak also increased with increasing $\mathrm{CO}$ exposure temperature. This shift with temperature and the change in relative peak intensities are consistent with the carbon surface coverage increasing with increasing $\mathrm{CO}$ exposure temperature. Increasing coverage results in weaker binding, thus the desorption peaks would shift to lower temperatures, as was observed. Moreover, at higher exposure temperatures, the less reactive sites would be capable of CO dissociation. Therefore, the least reactive sites (lowest desorption temperatures $-\alpha$ peak) would be occupied last, thus causing an increase in the intensity ratio for the $\alpha$ peak compared to the $\beta$ peak. 
Interestingly, for both the $\mathrm{Mo}_{2} \mathrm{C}$ and $\mathrm{Mo}_{2} \mathrm{~N}$ catalysts, negligible amounts of $\mathrm{H}_{2} \mathrm{O}$ were produced during the $\mathrm{H}_{2}$ TPRxn (Fig. S5), suggesting that oxygen adsorbed on the surface from $\mathrm{CO}$ dissociation either remained tightly bound to the surface, diffused into the subsurface, or was removed via reaction with adsorbed carbon or $\mathrm{CO}$ to produce $\mathrm{CO}$ or $\mathrm{CO}_{2}$, respectively. St. Clair et al. reported that adsorbed oxygen diffused into the bulk of $\alpha-\mathrm{Mo}_{2} \mathrm{C}(0001)$ during an $\mathrm{O}_{2}$ TPD instead of burning off as $\mathrm{CO}$ [36]. The production of $\mathrm{CO}_{2}$ during the $\mathrm{H}_{2}$ TPRxn over the $\mathrm{Mo}_{2} \mathrm{C}$ and $\mathrm{Mo}_{2} \mathrm{~N}$ catalysts is also shown in Fig. S5. A negligible amount of $\mathrm{CO}_{2}$ was produced over $\mathrm{Mo}_{2} \mathrm{C}$; however, $\mathrm{Mo}_{2} \mathrm{~N}$ exhibited a peak at $\sim 250{ }^{\circ} \mathrm{C}$ and the peak intensity and temperature decreased with increasing $\mathrm{CO}$ exposure temperature. These results, combined with the observed $\mathrm{CO}_{2}$ production over the $\mathrm{Mo}_{2} \mathrm{C}$ catalyst during the TPD step (Fig. S4), suggest that adsorbed oxygen is preferentially removed via reduction by $\mathrm{CO}$ to produce $\mathrm{CO}_{2}$, in accordance with the high WGS activities for these materials.

In addition to $\mathrm{CO}$ dissociation and hydrogenation, the experimental sequence shown in Fig. 1 allowed for the investigation of the effect of molecularly vs. dissociatively adsorbed CO on the production of hydrocarbons. The TPD step (Step 3) removed molecularly adsorbed CO. By skipping this step, molecularly adsorbed $\mathrm{CO}$ would be expected to remain on the catalyst surface and its impact on hydrocarbon production during the $\mathrm{H}_{2}$ TPRxn step (Step 4) can be investigated. Fig. 9 shows the MS intensity for $\mathrm{m} / \mathrm{z}=15$ and $\mathrm{m} / \mathrm{z}=29$ during the $\mathrm{H}_{2}$ TPRxn step over the $\mathrm{Mo}_{2} \mathrm{C}$ catalyst for which the Ar TPD step was either performed or not performed. The $\mathrm{m} / \mathrm{z}=29$ corresponds to $\mathrm{C}_{2} \mathrm{H}_{5}$ fragments, which almost all $\mathrm{C}_{2+}$ hydrocarbons produce. Two $\mathrm{CO}$ exposure temperatures were tested: $240{ }^{\circ} \mathrm{C}$ and RT. For CO exposure at $240{ }^{\circ} \mathrm{C}$, an increase in hydrocarbon production was observed over the $\mathrm{Mo}_{2} \mathrm{C}$ catalyst in the temperature range of $100-200{ }^{\circ} \mathrm{C}$ when the TPD step was not performed (i.e., molecularly adsorbed CO remained on 
the surface). This result was amplified for $\mathrm{CO}$ exposure at RT. These findings indicate that molecularly adsorbed CO plays a key role in hydrocarbon production. Moreover, the effect of molecularly adsorbed $\mathrm{CO}$ on $\mathrm{C}-\mathrm{C}$ coupling $\left(\mathrm{C}_{2+}\right.$ hydrocarbon production) was explored. As shown in Fig. 9c-d, the presence of molecularly adsorbed CO resulted in a significant increase in the production of $\mathrm{C}_{2+}$ hydrocarbons $(\mathrm{m} / \mathrm{z}=29)$, indicating that $\mathrm{CO}_{\text {ads }}$ plays a key role in $\mathrm{C}-\mathrm{C}$ coupling.
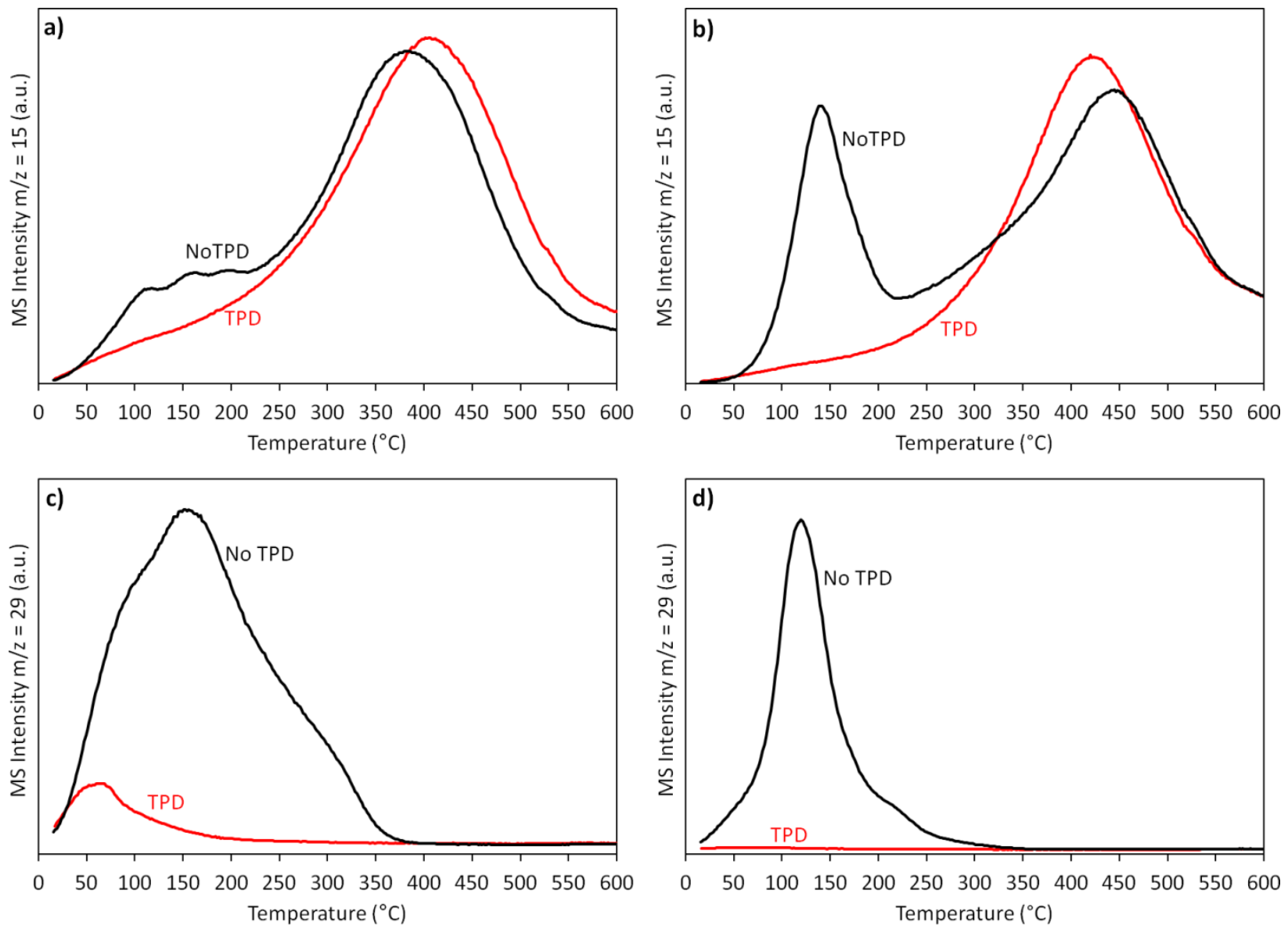

Fig. 9. $\mathrm{H}_{2}$ TPRxn spectra for the $\mathrm{Mo}_{2} \mathrm{C}$ catalyst, for which the Ar TPD step was either performed or not performed. Production of $\mathrm{CH}_{3}$ fragments $(\mathrm{m} / \mathrm{z}=15)$ for $\mathrm{CO}$ exposure temperatures of (a) $240{ }^{\circ} \mathrm{C}$ and (b) RT. Production of $\mathrm{C}_{2} \mathrm{H}_{5}$ fragments $(\mathrm{m} / \mathrm{z}=29)$ for $\mathrm{CO}$ exposure temperatures of (c) $240{ }^{\circ} \mathrm{C}$ and (d) RT.

\subsection{Mechanism Interpretations}


The interactions of $\mathrm{CO}$ and $\mathrm{H}_{2}$ with the $\mathrm{Mo}_{2} \mathrm{C}$ and $\mathrm{Mo}_{2} \mathrm{~N}$ surfaces were investigated to explain differences observed in the FTS rates as well as shed light on the FTS mechanism. Based on results from the TPD and TPRxn experiments, the $\mathrm{Mo}_{2} \mathrm{C}$ and $\mathrm{Mo}_{2} \mathrm{~N}$ catalysts adsorb molecular CO with similar binding energies $\left(90-150 \mathrm{~kJ} \mathrm{~mol}^{-1}\right)$. However, at $240{ }^{\circ} \mathrm{C}, \mathrm{CO}$ dissociation occurred readily over the $\mathrm{Mo}_{2} \mathrm{C}$ surface while temperatures at or above $280{ }^{\circ} \mathrm{C}$ were required to dissociate $\mathrm{CO}$ over the $\mathrm{Mo}_{2} \mathrm{~N}$ surface (Fig. 8). This result is consistent with the FTS (Fig. 3) and $\mathrm{H}_{2}-\mathrm{CO}$ TPRxn results (Fig. 4), as the $\mathrm{Mo}_{2} \mathrm{~N}$ catalyst did not yield measurable FTS activity below $270{ }^{\circ} \mathrm{C}$. One could conclude that that $\mathrm{CO}$ dissociation is a key step during FTS over the $\mathrm{Mo}_{2} \mathrm{~N}$ catalyst. The $\mathrm{Mo}_{2} \mathrm{C}$ and $\mathrm{Mo}_{2} \mathrm{~N}$ surfaces were capable of direct $\mathrm{CO}$ dissociation without the assistance of $\mathrm{H}_{2}$, given the absence of $\mathrm{H}_{2}$ during the experimental sequence.

From the $\mathrm{H}_{2}$ TPRxn experiments (Fig. 8), we learned that as the $\mathrm{CO}$ exposure temperature was increased, the intensity of the $\mathrm{CH}_{4}$ desorption peaks increased for both the $\mathrm{Mo}_{2} \mathrm{C}$ and $\mathrm{Mo}_{2} \mathrm{~N}$ catalysts. These $\mathrm{CH}_{4}$ desorption peaks were centered at $\sim 450$ and $\sim 150{ }^{\circ} \mathrm{C}$ for the $\mathrm{Mo}_{2} \mathrm{C}$ and $\mathrm{Mo}_{2} \mathrm{~N}$ catalysts, respectively. This difference in desorption temperature indicated that the carbon was bound much more strongly to the $\mathrm{Mo}_{2} \mathrm{C}$ surface than the $\mathrm{Mo}_{2} \mathrm{~N}$ surface. The high $\mathrm{CH}_{4}$ desorption temperature observed for the $\mathrm{Mo}_{2} \mathrm{C}$ catalyst is consistent with density functional theory calculations, in which the binding energy of carbon was reported to be very high, between -630 and $-725 \mathrm{~kJ} \mathrm{~mol}^{-1}$, depending upon the adsorption site [51]. Moreover, the high temperature $\mathrm{CH}_{4}$ desorption peaks for the $\mathrm{Mo}_{2} \mathrm{C}$ catalyst occurred over a similar temperature range as those for the material that was not exposed to $\mathrm{CO}$; the $\mathrm{CH}_{4}$ desorption peaks from the material that was not exposed to $\mathrm{CO}$ are due to the hydrogenation of carbidic carbon (i.e., carbon that is part of the $\mathrm{Mo}_{2} \mathrm{C}$ structure). Similar results have been reported by Miyao et al., in which they observed the reduction of surface carbidic carbon for $\mathrm{Mo}_{2} \mathrm{C}$ at $\sim 490$ 
${ }^{\circ} \mathrm{C}$ [52]. This result suggests that $\mathrm{C}_{\mathrm{ads}}$, produced from dissociation of $\mathrm{CO}$, prefers to reside in sites that are similar to those normally occupied by carbidic carbon in the $\mathrm{Mo}_{2} \mathrm{C}$ lattice.

We propose that the activation barrier for $\mathrm{CO}$ dissociation is higher for the $\mathrm{Mo}_{2} \mathrm{~N}$ catalyst than the $\mathrm{Mo}_{2} \mathrm{C}$ catalyst, and that this difference explains the observed difference in FTS rates. This higher activation barrier is consistent with the higher light off temperature (Fig. 4). Moreover, based on the Bronsted-Evans-Polanyi relationship, the activation energy for dissociative adsorption of molecules depends linearly on the reaction energy [53-57]. More specifically, the activation energy for $\mathrm{CO}$ dissociation is directly related to the dissociative $\mathrm{CO}$ adsorption energy. Accordingly, if the activation energy of $\mathrm{CO}$ dissociation decreases, then $\mathrm{C}$ and $\mathrm{O}$ will be bound more strongly to the catalyst surface. Our findings are consistent with this relationship as the $\mathrm{Mo}_{2} \mathrm{C}$ catalyst had a lower $\mathrm{CO}$ dissociation activation energy than the $\mathrm{Mo}_{2} \mathrm{~N}$ catalyst, and carbon was bound more strongly to $\mathrm{Mo}_{2} \mathrm{C}$ than to $\mathrm{Mo}_{2} \mathrm{~N}$. Regarding the FTS activities, Bligaard et al. reported that the dissociative $\mathrm{CO}$ adsorption energy is a good descriptor for the $\mathrm{CO}$ hydrogenation activities of transition metal catalysts ( $\mathrm{Re}, \mathrm{Fe}, \mathrm{Ru}, \mathrm{Co}, \mathrm{Rh}, \mathrm{Ni}, \mathrm{Ir}, \mathrm{Pd}$, and $\mathrm{Pt}$ ) [57]. Consequently, materials with different $\mathrm{CO}$ dissociation activation energies $\left(\mathrm{Mo}_{2} \mathrm{C}\right.$ vs. $\mathrm{Mo}_{2} \mathrm{~N}$ ) would be expected to exhibit different activities for $\mathrm{CO}$ hydrogenation.

Since the $\mathrm{Mo}_{2} \mathrm{C}$ and $\mathrm{Mo}_{2} \mathrm{~N}$ catalysts were active for direct $\mathrm{CO}$ dissociation, one might assume that FTS occurred via the carbide mechanism (Fig. 10). However, for the $\mathrm{Mo}_{2} \mathrm{C}$ catalyst, the desorption of $\mathrm{CH}_{4}$ produced from hydrogenation of adsorbed carbon occurred primarily at temperatures above $350^{\circ} \mathrm{C}$. This temperature is higher than the temperatures employed during the FTS experiments, suggesting that adsorbed carbon from $\mathrm{CO}$ dissociation might remain bound to the $\mathrm{Mo}_{2} \mathrm{C}$ surface under reaction conditions. On the other hand, the $\mathrm{CH}_{4}$ desorption peaks for the $\mathrm{Mo}_{2} \mathrm{~N}$ catalyst were between 100 and $250^{\circ} \mathrm{C}$, within the typical temperature range for the 
FTS experiments. Additionally, FTS activity was not observed for the $\mathrm{Mo}_{2} \mathrm{~N}$ catalyst until CO dissociation was favorable. Therefore, it is probable that FTS occurred via the carbide mechanism for the $\mathrm{Mo}_{2} \mathrm{~N}$ catalyst.

\section{Carbide Mechanism}

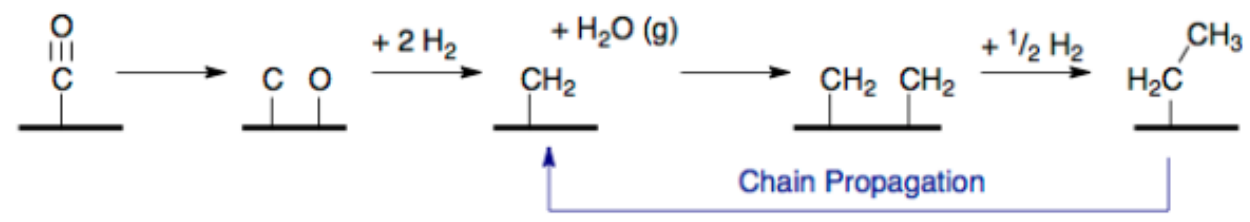

\section{Oxygenate (enol) Mechanism}

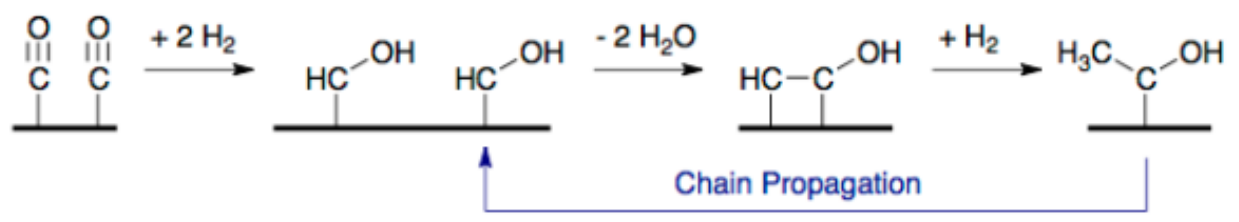

\section{CO Insertion Mechanism}

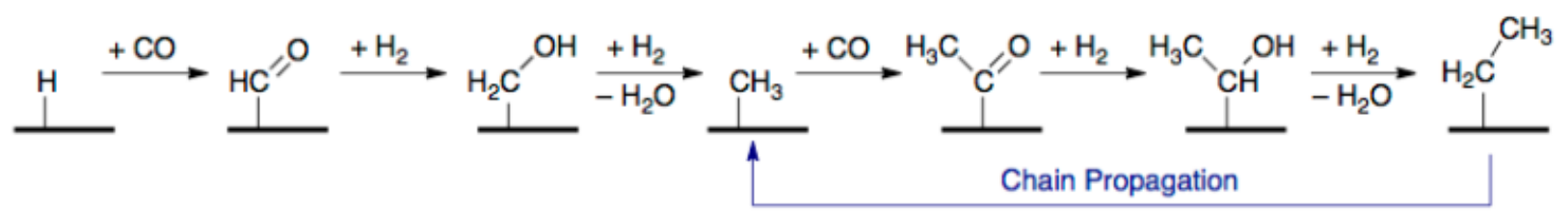

Fig. 10. Schematic showing the 3 primary FTS mechanisms: the carbide mechanism, the oxygenate mechanism, and the $\mathrm{CO}$ insertion mechanism. Adapted from [33, 58].

By exploring the effect of molecularly adsorbed $\mathrm{CO}$ vs. dissociatively adsorbed $\mathrm{CO}$ on reactivity, the mechanism for the $\mathrm{Mo}_{2} \mathrm{C}$ catalyst was elucidated. As shown in Fig. 10, CO dissociation is required for the carbide mechanism, whereas the oxygenate and $\mathrm{CO}$ insertion mechanisms involve molecular $\mathrm{CO}$ adsorption. Fig. 9 shows that the presence of molecularly adsorbed $\mathrm{CO}$ on the $\mathrm{Mo}_{2} \mathrm{C}$ surface resulted in an increase in hydrocarbon production as well as C-C coupling (production of $\mathrm{C}_{2+}$ hydrocarbons). These findings implicate an oxygenate species as the key reactive intermediate. In addition, since hydrogen was not pre-adsorbed to the surface prior to the $\mathrm{H}_{2}$ TPRxn experiments, these results suggest that the dominant pathway over the $\mathrm{Mo}_{2} \mathrm{C}$ catalyst was the oxygenate mechanism. Kojima et al. [4] speculated that the mechanism 
for $\mathrm{CO}$ hydrogenation over $\mathrm{Mo}_{2} \mathrm{C}$ involved the formation of $\mathrm{CH}_{\mathrm{x}} \mathrm{O}$ intermediate, and Medford et al. [22] reported, based on computational results, that coupling of HCO species was more favorable than coupling of $\mathrm{CH}_{\mathrm{x}}$ species over $\mathrm{Mo}_{2} \mathrm{C}$. Results reported in our paper are consistent with these findings. Furthermore, alcohols are expected to be side-products from the oxygenate mechanism. Similar to the Fe-based catalysts which have also been reported to follow the oxygenate mechanism [58], the $\mathrm{Mo}_{2} \mathrm{C}$ catalyst produced alcohols during FTS. Finally, the TPD and TPRxn results reported in this paper suggest that the $\mathrm{Mo}_{2} \mathrm{C}$ catalyst possessed at least two different types of catalytic sites: (i) $\mathrm{CO}$ dissociation sites and (ii) molecular $\mathrm{CO}$ adsorption sites that facilitate $\mathrm{C}-\mathrm{C}$ coupling reactions. It may be possible to improve $\mathrm{C}-\mathrm{C}$ coupling over the $\mathrm{Mo}_{2} \mathrm{C}$ catalyst by enhancing its ability for associative $\mathrm{CO}$ adsorption (e.g., increasing the number of sites for molecular $\mathrm{CO}$ adsorption).

\section{Conclusions}

The catalytic properties of a series of high surface area early transition metal carbides and nitrides $\left(\mathrm{Mo}_{2} \mathrm{C}, \mathrm{Mo}_{2} \mathrm{~N}, \mathrm{~W}_{2} \mathrm{C}, \mathrm{W}_{2} \mathrm{~N}, \mathrm{VC}, \mathrm{VN}, \mathrm{NbC}\right.$, and $\left.\mathrm{NbN}\right)$ were evaluated for FTS under industrially-relevant conditions. The activity trend based on TOFs was $\mathrm{Mo}_{2} \mathrm{C} \sim \mathrm{W}_{2} \mathrm{C} \sim \mathrm{VN} \sim$ $\mathrm{NbN}>\mathrm{Mo}_{2} \mathrm{~N} \sim \mathrm{W}_{2} \mathrm{~N}>\mathrm{VC} \sim \mathrm{NbC}$. The $\mathrm{Mo}_{2} \mathrm{C}$ catalyst exhibited a TOF that was an order of magnitude higher than that for the $\mathrm{Mo}_{2} \mathrm{~N}$ catalyst; this difference was attributed to a significantly higher activation barrier for direct $\mathrm{CO}$ dissociation for the $\mathrm{Mo}_{2} \mathrm{~N}$ catalyst. While both materials were capable of direct $\mathrm{CO}$ dissociation, only the $\mathrm{Mo}_{2} \mathrm{~N}$ catalyst appeared to follow the carbide mechanism. Based on results from TPD and TPRxn experiments, the pathway for C-C coupling over the $\mathrm{Mo}_{2} \mathrm{C}$ surface included an oxygenate intermediate.

Based on the observed product selectivities, demonstrated WGS activity, and the dominant reaction mechanism for $\mathrm{C}-\mathrm{C}$ coupling, potential applications for the carbides and 
nitrides include (i) conversion of biomass-derived syngas into light olefins, and (ii) coupling oxygenate species derived from biomass sources. Due to the availability of multiple types of catalytic sites and the ability to vary reactivity based on metal/non-metal atom, it may be possible to tune the properties of these materials to affect reactions of interest. Future work will be focused in this area.

\section{Acknowledgments}

This work was supported by funding from the National Science Foundation (CBET0933239) and the Hydrogen Energy Technology Laboratory at the University of Michigan.

\section{Appendix A. Supplementary Material}

Supplementary data associated with this article, including Figs. S1-S5 and Tables S1 and $\mathrm{S} 2$, can be found in the online version.

\section{References}

[1] Y.-C. Lin, G.W. Huber, Energy Environ. Sci. 2 (2009) 68-80.

[2] H.M.T. Galvis, J.H. Bitter, C.B. Khare, M. Ruitenbeek, A.I. Dugulan, K.P. de Jong, Science 335 (2012) 835-838.

[3] I. Kojima, E. Miyazaki, I. Yasumori, J. Chem. Soc., Chem. Commun. (1980) 573-574.

[4] I. Kojima, E. Miyazaki, J. Catal. 89 (1984) 168-171.

[5] I. Kojima, E. Miyazaki, Y. Inoue, I. Yasumori, Bull. Chem. Soc. Jpn. 58 (1985) 611-617.

[6] G. Ranhotra, A. Bell, J. Reimer, J. Catal. 108 (1987) 40-49.

[7] H.-G. Kim, K.H. Lee, J.S. Lee, Res. Chem. Intermed. 26 (2000) 427-443.

[8] P.M. Patterson, T.K. Das, B.H. Davis, Appl. Catal. A 251 (2003) 449-455.

[9] A. Griboval-Constant, J.-M. Giraudon, G. Leclercq, L. Leclercq, Appl. Catal. A 260 (2004) 35-45. 
[10] A. Griboval-Constant, J.-M. Giraudon, I. Twagishema, G. Leclercq, M.E. Rivas, J. Alvarez, M. Perez-Zurita, M. Goldwasser, J. Mol. Catal. A: Chem. 259 (2006) 187-196.

[11] H.C. Woo, K.Y. Park, Y.G. Kim, J.S. Lee, Appl. Catal. 75 (1991) 267-280.

[12] M. Xiang, D. Li, W. Li, B. Zhong, Y. Sun, Fuel 85 (2006) 2662-2665.

[13] J. Patt, D. Moon, C. Phillips, L. Thompson, Catal. Lett. 65 (2000) 193-195.

[14] N.M. Schweitzer, J.A. Schaidle, O.K. Ezekoye, X. Pan, S. Linic, L.T. Thompson, J. Am. Chem. Soc. 133 (2011) 2378-2381.

[15] M. Saito, R. Anderson, J. Catal. 63 (1980) 438-446.

[16] J.S. Lee, M.H. Yeom, D.-S. Lee, J. Mol. Catal. 62 (1990) L45-L51.

[17] K.Y. Park, W.K. Seo, J.S. Lee, Catal. Lett. 11 (1991) 349-356.

[18] D.-V.N. Vo, A.A. Adesina, Appl. Catal. A 399 (2011) 221-232.

[19] M. Xiang, D. Li, H. Xiao, J. Zhang, H. Qi, W. Li, B. Zhong, Y. Sun, Fuel 87 (2008) 599603.

[20] H. Shou, R.J. Davis, J. Catal. 282 (2011) 83-93.

[21] H. Shou, R.J. Davis, J. Catal. 306 (2013) 91-99.

[22] A.J. Medford, A. Vojvodic, F. Studt, F. Abild-Pedersen, J.K. Nørskov, J. Catal. 290 (2012) 108-117.

[23] H. Ren, Y. Chen, Y. Huang, W. Deng, D.G. Vlachos, J.G. Chen, Green Chem. 16 (2014) 761-769.

[24] K. Xiong, W. Yu, J.G. Chen, Appl. Surf. Sci. 323 (2014) 88-95.

[25] W.-S. Lee, Z. Wang, R.J. Wu, A. Bhan, J. Catal. 319 (2014) 44-53.

[26] J.A. Schaidle, A.C. Lausche, L.T. Thompson, J. Catal. 272 (2010) 235-245.

[27] A.C. Lausche, J.A. Schaidle, L.T. Thompson, Appl. Catal. A 401 (2011) 29-36. 
[28] J.A. Schaidle, N.M. Schweitzer, O.T. Ajenifujah, L.T. Thompson, J. Catal. 289 (2012) 210-217.

[29] J.-G. Choi, R.L. Curl, L.T. Thompson, J. Catal. 146 (1994) 218-227.

[30] M. Neylon, S. Choi, H. Kwon, K. Curry, L. Thompson, Appl. Catal. A 183 (1999) 253263.

[31] J.B. Claridge, A.P. York, A.J. Brungs, M.L. Green, Chem. Mater. 12 (2000) 132-142.

[32] R.B. Anderson, Catalysts for the Fischer-Tropsch Synthesis, Van Nostrand-Reinhold, New York, 1956.

[33] G.P. Van Der Laan, A. Beenackers, Catal. Rev. 41 (1999) 255-318.

[34] S.L. Schroeder, M. Gottfried, Temperature-Programmed Desorption (TPD) Thermal Desorption Spectroscopy (TDS), Berlin, 2002.

[35] P. Redhead, Vacuum 12 (1962) 203-211.

[36] T.P. St Clair, S.T. Oyama, D.F. Cox, Surf. Sci. 468 (2000) 62-76.

[37] H.S. Kim, C.H. Shin, G. Bugli, M. Bureau-Tardy, G. Djega-Mariadassou, Appl. Catal. A 119 (1994) 223-240.

[38] S. T. Oyama, J. C. Schlatter, J. E. Metcalfe III, J. M. Lambert Jr., Ind. Eng. Chem. Res. 27 (1988) 1639-1648.

[39] S. Ramanathan, S. T. Oyama, J. Phys. Chem. 99 (1995) 16365-16372.

[40] M.A. Vannice, W.H. Joyce, Kinetics of catalytic reactions, Springer, 2005.

[41] S. Bej, L. Thompson, Appl. Catal. A 264 (2004) 141-150.

[42] F.H. Ribeiro, A.E. Schach von Wittenau, C.H. Bartholomew, G.A. Somorjai, Catal. Rev. 39 (1997) 49-76. 
[43] J.S. Lee, M.H. Yeom, K.Y. Park, I.-S. Nam, J.S. Chung, Y.G. Kim, S.H. Moon, J. Catal. 128 (1991) 126-136.

[44] S. Oyama, Catal. Today 15 (1992) 179-200.

[45] T.P.S. Clair, B. Dhandapani, S. Oyama, Catal. Lett. 58 (1999) 169-171.

[46] Y. Borodko, G. Somorjai, Appl. Catal. A 186 (1999) 355-362.

[47] J. Chen, Z.-P. Liu, J. Am. Chem. Soc. 130 (2008) 7929-7937.

[48] J. Cheng, P. Hu, P. Ellis, S. French, G. Kelly, C.M. Lok, J. Phys. Chem. C 112 (2008) 6082-6086.

[49] J. Yang, Y. Liu, J. Chang, Y.-N. Wang, L. Bai, Y.-Y. Xu, H.-W. Xiang, Y.-W. Li, B. Zhong, Ind. Eng. Chem. Res. 42 (2003) 5066-5090.

[50] C.G. Visconti, E. Tronconi, L. Lietti, R. Zennaro, P. Forzatti, Chem. Eng. Sci. 62 (2007) 5338-5343.

[51] J. Ren, C.-F. Huo, J. Wang, Z. Cao, Y.-W. Li, H. Jiao, Surf. Sci. 600 (2006) 2329-2337.

[52] T. Miyao, I. Shishikura, M. Matsuoka, M. Nagai, S. T. Oyama, Appl. Catal. A 165 (1997) 419-428.

[53] J.K. Nørskov, T. Bligaard, A. Logadottir, S. Bahn, L.B. Hansen, M. Bollinger, H. Bengaard, B. Hammer, Z. Sljivancanin, M. Mavrikakis, J. Catal. 209 (2002) 275-278.

[54] V. Pallassana, M. Neurock, J. Catal. 191 (2000) 301-317.

[55] Z.-P. Liu, P. Hu, J. Chem. Phys. 114 (2001) 8244-8247.

[56] A. Logadottir, T.H. Rod, J.K. Nørskov, B. Hammer, S. Dahl, C. Jacobsen, J. Catal. 197 (2001) 229-231.

[57] T. Bligaard, J.K. Nørskov, S. Dahl, J. Matthiesen, C.H. Christensen, J. Sehested, J. Catal. 224 (2004) 206-217. 
[58] B.H. Davis, Catal. Today 141 (2009) 25-33. 


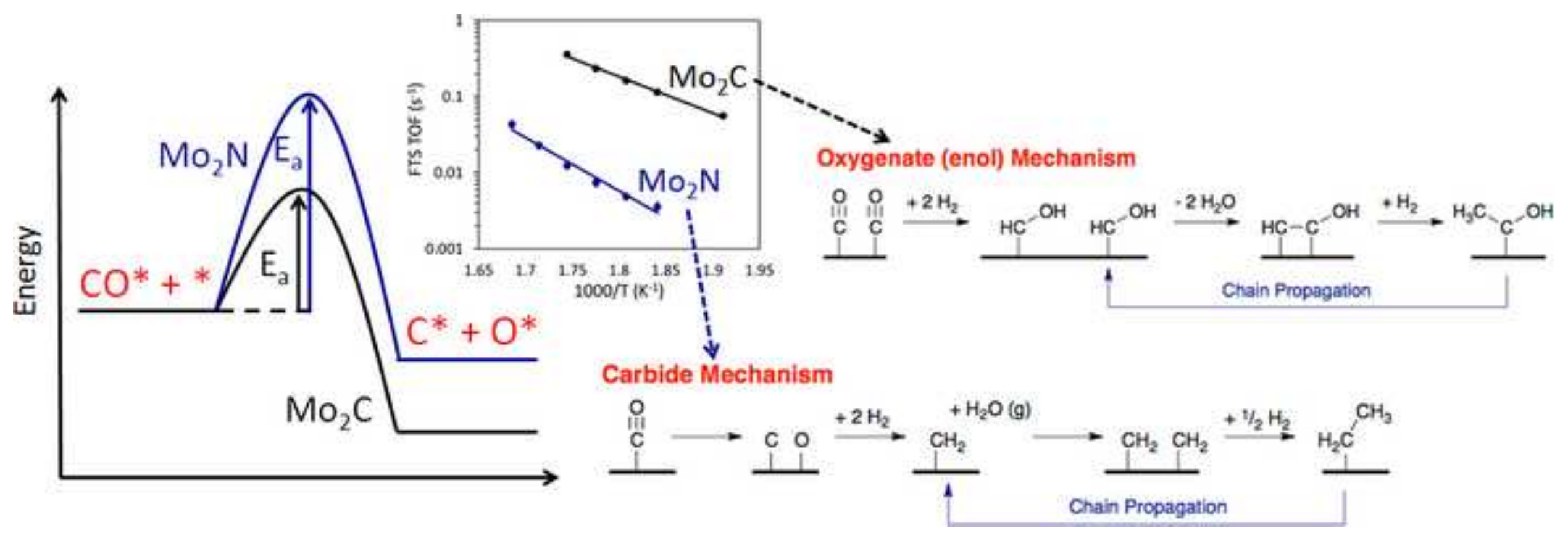

